\title{
On Thin Ice? Arctic Indigenous Communities, the European Union and the Sustainable Use of Marine Mammals
}

\author{
Martin Hennig and Richard Caddell
}

It's okay to eat fish, 'cause they don't have any feelings'. NIRVANA, Something in the Way

Since 2008, the strategic policy objectives of the European Union (EU) in the High North have been to protect and preserve the Arctic in unison with its population, to promote the sustainable use of resources and to contribute to enhanced multilateral governance for this region. ${ }^{1}$ More recently, the EU Arctic Policy statement of April 2016 has entrenched supranational commitments to taking account of the traditional livelihoods of the region's indigenous inhabitants and the impact of economic development on its fragile environment, so as to 'contribute to enhancing the economic, social and environmental resilience of societies in the Arctic', while also promoting these objectives through pertinent international fora. ${ }^{2}$

* Martin Hennig, Postdoctoral Research Fellow, Faculty of Law, UiT The Arctic University of Norway, Tromsø, Norway (martin.hennig@uit.no).

** Richard Caddell, Senior Research Associate and Nippon Foundation Senior Nereus Fellow, Netherlands Institute for the Law of the Sea, Utrecht University, The Netherlands (j.r.caddell@ uu.nl); Lecturer in Law, Cardiff University, UK; Dr Caddell gratefully acknowledges funding from the Nippon Foundation's Nereus Program (www.nereusprogram.org) in facilitating this contribution.

1 Communication from the Commission to the European Parliament and the Council: The European Union and the Arctic Region сом (2008) 763, 3.

2 Joint Communication to the European Parliament and the Council: An Integrated European Union Policy for the Arctic JoIN (2016) 21, 3-4. 
Within this relatively truncated timeframe, however, few issues have arguably straddled these overarching policy priorities less comfortably for the EU institutions than the regulation of marine mammals in this region. For many Arctic peoples, the sustainable use of marine mammals remains fundamental to their traditional ways of life and carries great cultural as well as economic significance. Nevertheless, in many European areas outside the Arctic, the hunting of seals and whales has long been considered highly controversial and frequently generates strong and vociferous concerns over animal welfare. ${ }^{3}$ This dichotomy has created significant legislative and policy difficulties for the EU institutions, requiring a delicate balancing act in upholding key human rights commitments towards indigenous peoples, while also promoting animal welfare standards as mandated under the EU Treaty. Moreover, the EU has long opposed the commercial harvesting of marine mammals, advancing a common position against these activities in relevant multilateral organizations and adopting an array of legislation to bar such products from the internal market. While seeking to uphold the long-standing special status of traditional enterprises, significant shortcomings have nevertheless become apparent in the ability of the EU to legislate surgically to protect the economic and social rights of a full range of indigenous Arctic communities, while pursuing measures to inhibit the market presence of commercially-derived marine mammal products. This has proved to be especially true in the context of seal products, where the introduction of a series of flawed restrictions on the sale of such items within the common market has damaged the relationship between the EU institutions and Arctic communities in recent years. Although these measures were purportedly well-intentioned towards the Arctic peoples of Europe, concerns have nonetheless been raised within these communities as

3 Indeed, early iterations of EU policies towards seals - which, as noted below, sought to address widespread public opprobrium over the bludgeoning of pups for their pelts-have been memorably described by EU officials as 'the only EC directive which appeared to have universal support among the European public': see Donald McGillivray, 'Seal Conservation Legislation in the UK-Past, Present, Future' (1995) 10 International Journal of Marine and Coastal Law 19, 48. In a similar vein, the hunting of seals continues to raise 'serious concerns' among members of the public and governments in EU Member States, as officially stated by Regulation (EC) No. 1007/2009 of the European Parliament and of the Council of 16 September 2009 on trade in seal products [2009] OJ L 286/36, preamblar recital (4). Meanwhile, commercial sealing has been largely banned by many other states outside the EU, including other Arctic jurisdictions, notably in the United States (US) under the Marine Mammal Protection Act 1972, which also applies an import exemption for noncommercial products 'owned by a Native inhabitant of Russia, Canada, or Greenland' under section 108.b 2 (B) [16 U.s.C. 1361 et seq.]. 
to whether the EU can be truly considered a consistent and helpful partner in securing the survival of traditional activities involving the sustainable use of marine mammals.

This Chapter therefore seeks to evaluate the extent to which the EU has been able to reconcile its longstanding support for the traditional practices of Arctic communities with its distinct policy objectives towards marine mammals, in the context of the ongoing development of its overarching strategy for the High North. To this end, Part 2 of this Chapter examines the 'EU Seal Regime' which, in 2009, introduced a general ban on the sale of seal products across the entirety of the EU. ${ }^{4}$ The ban, which came into effect in 2010, was met with fierce opposition from, among others, Canadian Inuit seal hunters, whose products were consequently excluded from the EU market. At the heart of the conflict lies the so-called 'IC exception', which creates a potential exemption from the ban for seal products derived from hunts conducted by indigenous communities, whereas access to EU markets is precluded for products yielded from purely 'commercial' hunts conducted by non-indigenous hunters. Thus far, however, due to the burdensome criteria incumbent in invoking the IC exception, these provisions have essentially operated to the sole benefit of Greenlandic Inuit seal hunters, in marked contrast to their counterparts from other indigenous Arctic communities. Opposition to the 'EU Seal Regime' duly resulted in a series of actions before the Court of Justice of the European Union (CJEU), which now spans a total of four separate judgments. The crux of this litigation involved the economic position of Canadian Inuit seal hunters, who contended that there is no basis within the EU Treaties to ban seal products and that these trade restrictions violated the fundamental rights of indigenous peoples. While these arguments having been rejected by the CJEU, this odyssey of litigation has continued further, with the 'EU Seal

4 For the purposes of this Chapter, the 'EU Seal Regime' refers to the series of provisions introduced by the EU since 2009, namely Regulation (EC) No. 1007/2009 (n. 3) as amended by Regulation (EU) 2015/1775 of the Parliament and of the Council of 6 October 2015 amending Regulation (EC) No 1007/2009 on trade in seal products and repealing Commission Regulation (EU) No 737/2010, [2015] OJ L 262/1, together with Commission Implementing Regulation (EU) 2015/1850 of 13 October 2015 laying down detailed rules for the implementation of Regulation (EC) No 1007/2009 of the European Parliament and of the Council on trade in seal products [2015] oJ L 216/1.. These instruments, as well as their early and equally contentious forerunners, are discussed below. Given the extensive contemporaneous literature on the development of the individual Regulations, in assessing the treatment of seal products this Chapter focuses primarily on the implications of the recent case law for indigenous Arctic communities. For a comprehensive analysis of the development of Regulation 1007/2009 see Nikolas Sellheim, 'The Neglected Tradition-The Genesis of the EU Seal Products Ban and Commercial Sealing' (2013) 5 Yearbook of Polar Law 417, 419-444. 
Regime' subject to lengthy proceedings before the World Trade Organization (WTO) dispute settlement system. In 2014, the WTO appellate body eventually ruled that the de facto exclusion of Canadian Inuit seal products from the $\mathrm{EU}$ market was unlawful and discriminatory. Based on an analysis of the extensive case law and recent amendments to this legislation introduced in an attempt to excise the discriminatory aspects of the IC exception, it is asked whether the 'EU Seal Regime' can now be considered to be in full compliance with the fundamental rights of indigenous peoples. This Chapter argues that while the EU lawmakers may have finally brought the Seal Regime into broad compliance with wто law, the tacit promotion of Greenlandic interests and the long exclusion from the market of products derived from other communities has already inflicted serious and long-term damage to the social and economic rights of the Canadian Inuit.

As with seal hunting, whaling is also a politically sensitive issue for the EU. As explored in Part 3 of this Chapter, the commercial harvesting of cetaceans (whales, dolphins and porpoises) has been consistently and staunchly opposed by the EU institutions, with heavy restrictions having been imposed upon the trade in such products within the internal market. This position notwithstanding, considerable allowances have been made for non-commercial hunting as practiced predominantly in the High North, with market restrictions applied in a manner that has largely avoided the controversies raised by the Eu Seal Regime. Instead, the treatment of so-called 'Aboriginal Subsistence Whaling' and the trade in cetacean products presents a useful case-study of the role of the EU as a partner to indigenous Arctic communities within multilateral organizations. This is especially true in the context of Greenland which, while outside the formal auspices of the EU itself, has been reliant upon the support of the EU institutions - and the legal contortions of the Danish authorities within this broader process-to pursue its ambitions for larger whaling quotas within the global regulatory body, the International Whaling Commission (IWC). While the Greenlandic Inuit can, on balance, be generally seen to have benefitted from this partnership with regard to the global regulation of whaling, the EU has nevertheless exhibited limited enthusiasm to engage with regional regulatory processes concerning the sustainable use of marine mammals in the Arctic. Moreover, the continued hunting of whales and seals in ever increasing numbers has generated disquiet as to the alleged quasi-commercial nature of these activities, which has started to test the conceptual limits of indigenous subsistence exemptions in pertinent regulatory and adjudicatory fora. Accordingly, as this Chapter demonstrates, the position of marine mammals will continue to pose an intriguing challenge to present and future EU Arctic policies, both within and beyond the formal borders of the Community. 


\subsection{The Background to the $\mathrm{E} U$ Seal Regime and its Legal Controversies}

Animal welfare considerations, especially towards highly charismatic species such as cetaceans and pinnipeds (seals, sea lions and walruses), have long been a preoccupation of European citizens and legislators alike. ${ }^{5}$ In response to these concerns, and the heavy political pressures that invariably accompany popular environmental causes, the $\mathrm{E} U$ has incrementally adopted an extensive body of animal welfare legislation, motivated to a considerable degree to meet the vociferous public demand for regulation in this field. ${ }^{6}$ Nevertheless, such measures - however well-meaning in origin and intent - have regularly transpired to be disproportionately problematic for the EU institutions, repeatedly generating political tensions with neighbouring States due to a marked over-reliance upon sweeping trade restrictions and a perceived lack of prior consultation. ${ }^{7}$ Furthermore, the purported exemption clauses contained

5 See McGillivray (n. 3) 48 (noting that the legal debate over seal culling has often turned more on 'ethics and popular sentiment' than competing environmental and economic factors); see also Katie Sykes, 'Sealing Animal Welfare into the GATT Exceptions: The International Dimension of Animal Welfare in WTO Disputes' (2014) 13 World Trade Review 471 and Kate Cook and David Bowles, 'Growing Pains: The Developing Relationship of Animal Welfare Standards and the World Trade Rules' (2010) 19 Review of European Community and International Environmental Law 227. Marine mammal conservation is not confined to supranational concern: the development of EU provisions to address the trade in pinniped and cetacean products has been regularly necessitated by the potentially distortive impact upon the common market of purported restrictions on the part of individual Member States, as was repeatedly cited in both the EU Seal Regime itself and the various judgments of the CJEU in response to challenges to this legislation.

6 Much of the current EU legislation on animal welfare addresses livestock, animal transportation, scientific experimentation and zoological standards and is generally limited in its treatment of marine species. Instead, seal welfare considerations have emerged on a largely ad hoc basis within specific measures pertaining to sealing and the trade in seal products. On the EU animal welfare standards applicable to seals see Robert L. Howse and Joanna Langille, 'Permitting Pluralism: The Seal Products Dispute and Why the WTO Should Accept Trade Restrictions Justified by Noninstrumental Moral Values' (2012) 37 Yale Journal of International Law 367, 373-379.

7 Indeed, the timing of the first iteration of the EU seal provisions angered the Canadian authorities, having been unilaterally introduced at a delicate point in an extensive-and ongoing - national review of seal hunting. The Canadian Royal Commission, charged with examining this issue, had been especially concerned with assessing the sustainability of these operations and their significance for the traditional ways of life of Arctic indigenous communities in developing targeted national legislation - a process that was then largely 
therein have often proved to be insufficiently nuanced to protect a full range of non-commercial interests from collateral economic harm, or have been rendered largely redundant since the practical effect of the measure in question has been to fundamentally undermine the market demand for particular products, irrespective of any special circumstances incumbent in their production. Consequently, such legislation rarely proceeds without challenge and frequently requires modification and subsequent interpretation based upon negotiations with external interests ${ }^{8}$ or, as in the context of seals, the intervention of a leading international adjudicatory body.

EU market restrictions on particular seal products - and their propensity to compromise the economic interests of indigenous Arctic peoples-date back over thirty years, with the adoption in 1983 of an equally contentious Directive addressing the trade in pelts of harp and hooded seals. ${ }^{9}$ At the material time, and in a similar manner to the development of the more recent $\mathrm{E} U \mathrm{U}$ Seal Regime, a number of Member States were considering the unilateral imposition of

usurped by the introduction of heavy restrictions by the EU on the trade in seal pelts; Albert H. Malouf, Seals and Sealing in Canada: Report of the Royal Commission: Volumes I and II (Ottawa, Canadian Government Publishing Centre, 1986).

8 This position is exemplified by the controversies raised by the introduction of Council Regulation (EEC) 3254/91 of 4 November 1991 prohibiting the use of leghold traps in the Community and the introduction into the Community of pelts and manufactured goods of certain wild animal species originating in countries which catch them by means of leghold traps or trapping methods which do not meet international humane trapping standards, [1991] OJ EC L 308/1 (popularly known as the 'Leghold Traps Regulation'). The Regulation, which was complemented by further standards listing countries from which specific products could be imported, drew a robust response from Canada, Russia and the us, which required its repeated postponement and a series of external agreements with these States. Attempts to reconstitute the Regulation as a more general measure addressing humane trapping standards were subsequently withdrawn by the Commission. For an illuminating discussion of the Regulation and its flaws see André Nollkaemper, "The Legality of Moral Crusades Disguised in Trade Laws: An Analysis of the EC "Ban” on Furs from Animals Taken by Leghold Traps' (1996) 8 Journal of Environmental Law 237.

9 Council Directive 83/129/EEC of 28 March 1983 concerning the importation into Member States of skins of certain seal pups and products derived therefrom [1983] oJ L 91/30. The Directive was initially conceived as a temporary measure, hence the ban was further extended in 1985 (Council Directive 85/444/EEC of 27 September 1985 amending Council Directive $83 / 129 /$ EEC concerning the importation into Member States of skins of certain seal pups and products derived therefrom [1985] oJ L 259/70) and applied indefinitely from 1989 onwards (Council Directive 89/370/EEC of 8 June 1989 amending Directive 83/129/EEC concerning the importation into Member States of skins of certain seal pups and products derived therefrom [1989] oJ L 163/37). 
trade restrictions upon sealskin, largely prompted by environmental campaigns that had generated an outcry in Western Europe over the clubbing of seal pups. Accordingly, so as to avoid uneven access conditions across the common market, the EC imposed blanket restrictions upon the commercial importation of a series of products derived from seal pelts. ${ }^{10}$ Although ostensibly introduced due to environmental factors-the Directive cites 'various studies' (albeit which were not further substantiated) that had 'raised doubts concerning the population status of the harp and hooded seals'11—critics consider the ecological case for the legislation to have been exaggerated. Indeed, the prevailing scientific evidence indicated that stock numbers were in fact highly buoyant, ${ }^{12}$ hence as Gillespie argues the Directive was instead founded upon 'considerations that had little to do with sustainability in a strict sense'13 and was seemingly driven more by popular revulsion over the clubbing of anthropomorphically appealing (yet numerically plentiful) seal pups.

As with the current iteration of the EU Seal Regime, Directive 83/129/EEC specifically addressed commercial enterprises and established an exemption clause for products 'resulting from traditional hunting by the Inuit people. ${ }^{14}$ To this end, the Directive pointedly — and perhaps with shades of undue paternalism-recognized such activities as 'a natural and legitimate occupation' that constituted 'an important part of the traditional way of life and economy' which is generally pursued in a manner that 'leaves seal pups unharmed and it is therefore appropriate to see that the interests of the Inuit people are not affected' 15 The exemption clause itself was not without interpretative

10 Article 1; the proscribed products were listed in an Annex to the Directive.

11 Preamble to the Directive.

12 In Canada, at least, from which a considerable proportion of commercial seal products were derived prior to the imposition of the EU restrictions, the Canadian Royal Commission concluded on the basis of considerable scientific evidence that " $t$ the populations of most species of seals were therefore increasing. This was especially the case for harp and hooded seals, whose elevated numbers actually presented new conservation problems in the form of increased scope for interactions with commercial and indigenous fisheries: Albert H. Malouf, Seals and Sealing in Canada: Report of the Royal Commission: Volume I (Ottawa, Canadian Government Publishing Centre, 1986) 25.

13 Alexander Gillespie, International Environmental Law, Policy, and Ethics (Oxford, Oxford University Press, 2014) 71-72; similar sentiments are expressed by Donald A. Reid, 'The EC Directive concerning the Importation of Skins of Certain Seal Pups (83/129/EEC): Its Compatibility with the General Agreement on Tariffs and Trade' (1996) 5 European Environmental Law Review 344, 344.

14 Article 3.

15 Preamble to the Directive. 
difficulties, however, not least since the notion of 'traditional hunting' was never expressly defined within the Directive. Indeed, this provision attracted suspicion in particular quarters due to its potential scope to constrain products that, while derived from the Inuit, might not necessarily have involved 'traditional' hunting methods on a strict construction of that term. ${ }^{16}$ This was an uncomfortable irony of the legislation, since a number of Inuit traders had duly amended their longstanding hunting practices to include the use of firearms in a bid to appease the animal welfare concerns raised by seal clubbing, which in turn increased the cost of production and rendered indigenous enterprises acutely vulnerable to market fluctuations. ${ }^{17}$ In the absence of any legal proceedings on this issue, these concerns appear to be somewhat unfounded in practice. ${ }^{18}$ Fears as to the adverse economic impacts of these provisions would, however, prove to be disconcertingly accurate. Despite the supposedly surgical application of the Directive, its financial implications did not discriminate between producers of seal pup products. Instead the measures precipitated a swift implosion of the European market for pelts, irrespective of origin, which had a disproportionately severe effect upon Inuit producers. ${ }^{19}$ An economically viable sealskin industry in Greenland was only restored some

16 George Wenzel, Animal Rights, Human Rights: Ecology, Economy and Ideology in the Canadian Arctic (Toronto, University of Toronto Press, 1991) 49 (attributing the wording of the exemption clause to the influence of '[a]nti-sealing activists' upon the legislators).

17 See further Malouf (n. 12) 13.

18 The precise meaning of this term was never fully resolved. The more recent seal legislation introduced by the $\mathrm{EU}$ has adopted a clearer-and more lenient-position on traditional hunting methods, although commentators have voiced concerns that there remains scope to restrict particular Inuit-derived products on this basis: Dorothée Cambou, 'The Impact of the Ban on Seal Products on the Rights of Indigenous Peoples: A European Issue' (2013) 5 Yearbook of Polar Law 389, 394-395.

19 Indeed, the Canadian Royal Commission observed that indigenous incomes plummeted by up to $85 \%$ in some instances: Malouf, (n. 12) 213. The drop in export value of sealskin consequently impinged significantly upon the ability of a number of indigenous communities to fund their regular subsistence activities: Wenzel (n. 16) 124. The human consequences of this dramatic reduction in income, as well as the loss of expression of traditional identities, are difficult to quantify. Nevertheless, this prospect certainly troubled the Canadian Royal Commission, which noted increased social hardships among its indigenous communities as a result: ibid., $245^{-256}$. In Greenland, significant 'social pathologies' were also observed in the wake of the ban, including a spike in suicides as individuals struggled with the loss of community respect attributed to non-participation in traditional hunting activities: M.M.R. Freeman et al., Inuit, Whaling, and Sustainability (Walnut Creek, AltaMira Press, 1998) 157. 
two decades subsequent to the introduction of these restrictions, ${ }^{20}$ while the social and cultural ramifications of the loss of these traditions for indigenous communities has been-and largely continues to be-overlooked in the ongoing review of market regulation.

Some twenty years subsequent to the indefinite application of the seal pup pelt ban, in September 2009 the European Parliament and the Council adopted Regulation 1007/2009 (the 'Basic Regulation'), which imposed a general prohibition on the import and marketing of all commercially-derived seal products within the EU internal market. ${ }^{21}$ This was a significant departure from the tenor of Directive 83/129/EC, which had prohibited the trade in products from particular seal pups but had left open the possibility of marketing pelts from older animals. Having been initially intended to reinforce the earlier Directives of the 1980s, so as to apply to all harp and hooded seal products, the Basic Regulation ultimately addressed 'specimens of all species of pinnipeds' following interventions within the European Parliament. ${ }^{22}$ Unlike its legislative forerunner, the 2009 Regulation made no claim as to the ecological necessity of a ban on such products, ${ }^{23}$ instead citing consumer anxieties over the origin of certain household products, the widespread concern for animal welfare and the practical need to pre-empt the distortive effect of differing national standards on market access to particular items. In 2010, in order to give practical effect to these amended trade standards, the European Commission adopted Regulation 737/2010 (the 'Implementing Regulation'). ${ }^{24}$ Due to subsequent litigation before the wTo, this provision was later repealed and replaced by Regulation 2015/1850. ${ }^{25}$

The imposition of a blanket ban on trade in all forms of seal products would have been harmful to indigenous peoples, to whom seal hunting has significant cultural and economic implications. The EU, in the form of the so-called 'IC

20 Nordic Council, Seals and Society (Copenhagen, Nordic Council of Ministers, 2008) 43.

21 Regulation (EC) No. $1007 / 2009$ (n. 3). The Basic Regulation was pre-empted by the introduction of national restrictions upon seal products by Belgium and The Netherlands in 2007.

Basic Regulation, art 2(1). On the legislative passage of these provisions, which included significant interventions by prominent animal welfare activists, see Sellheim (n. 4) 434-440.

Indeed, from a conservation perspective many seal populations are now considered to be numerous: see www.iucnredlist.org.

24 Commission Regulation (EU) No 737/2010 of 10 August 2010 laying down detailed rules for the implementation of Regulation (EC) No 1007/2009 of the European Parliament and of the Council on trade in seal products [2010] oJ L 216/1 (now repealed).

25 Commission Implementing Regulation (EU) 2015/1850 (n. 4). 
exception, ${ }^{26}$ has therefore expressly recognised the importance of permitting indigenous hunts and facilitating a degree of market access for such products. ${ }^{27}$ This exception is intended in particular to protect the fundamental economic and social interests of Inuit communities engaged in hunting, so as to ensure that their subsistence will not be adversely affected. ${ }^{28}$ Traditional seal hunting constitutes an integral part of the culture and identity of members of the Inuit society, and would appear to be recognized as such by the United Nations Declaration on the Rights of Indigenous Peoples. ${ }^{29}$ This instrument calls inter alia for indigenous communities to be 'secure in the enjoyment of their own means of subsistence and development, and to engage freely in all their traditional and other economic activities, ${ }^{30}$ and is expressly referenced in the preamble of the Basic Regulation. ${ }^{31}$ While not legally binding, given the traditional reliance upon seal products by the Inuit as a primary form of external trade, this provision would appear to provide a moral and political imperative for the $\mathrm{EU}$ authorities to facilitate a clear and workable exception to any purported restrictions on trade in publicly sensitive products such as sealskin. Accordingly, the EU Seal Regime was drafted in a more flexible manner to the preceding seal pup restrictions, with the Basic Regulation applying an expansive definition of 'Inuit' hunters ${ }^{32}$ and softening the previously stricter requirements for

26 The term 'IC exception' was used as shorthand by the wTo Dispute Settlement System to refer to the exemption granted to tradeable Inuit seal products that can be legitimately sold on the EU internal market; this Chapter accordingly uses this phrase in the same manner as the wTo.

27 Under art 3(1) of Regulation 737/2010, the IC exception provides that ' $\mathrm{t}$ ] $\mathrm{he}$ placing on the market of seal products shall be allowed only where the seal products result from hunts traditionally conducted by Inuit and other indigenous communities and contribute to their subsistence'. Limited non-commercial exemptions were also applied to goods that were for the occasional use of travelers and their families, as well as products derived from hunting conducted pursuant to national law for the purposes of promoting the sustainable management of marine resources (such as the culling of seals for stock control or veterinary reasons).

28 See Regulation 1007/2009, preambular recital (14). The recital further considers seal hunting to be an 'integral part' of the culture and society of Inuit communities.

29 UN General Assembly Resolution 61/295 of 13 September 2007.

30 Art 20(1). Furthermore, the Preamble to the Declaration recognises that 'respect for indigenous knowledge, cultures and traditional practices contributes to sustainable and equitable development and proper management of the environment'.

31 Preambular recital (2).

32 Under art 2(4), the IC exception applies to 'indigenous members of the Inuit homeland, namely those arctic and subarctic areas where, presently or traditionally, Inuit have aboriginal rights and interests, recognised by Inuit as being members of their people and 
'traditional' activities. ${ }^{33}$ These clauses are significant since, with the exception of the 1983 seal Directive, 'no other piece of EU secondary legislation has special provisions for the Inuit.' ${ }^{34}$

At first glance, the formulation of the IC exception seemingly reflects the blend of obligations incumbent upon EU lawmakers to reconcile the need to uphold the fundamental rights of indigenous peoples, as derived from pertinent external commitments, ${ }^{35}$ with the demands of animal welfare, as expressly established under art 13 of the Treaty on the Functioning of the European Union (TFEU), ${ }^{36}$ which requires that:

[i]n formulating and implementing the Union's agriculture, fisheries, transport, internal market, research and technological development and space policies, the Union and the Member States shall, since animals are sentient beings, pay full regard to the welfare requirements of animals, while respecting the legislative or administrative provisions and customs of the Member States relating in particular to religious rites, cultural traditions and regional heritage. ${ }^{37}$

includes Inupiat, Yupik (Alaska), Inuit, Inuvialuit (Canada), Kalaallit (Greenland) and Yupik (Russia)'. Broad recognition was also made of 'other indigenous communities' under art 2(1) of the 2010 Implementing Regulation, which raises an intriguing theoretical question as to the position of the small pockets of indigenous ethnic communities located elsewhere in the EU, albeit one that is highly unlikely ever to be invoked in practice. In contrast, art 3 of Directive 83/129/EEC merely referred to 'the Inuit people' with no further elaboration as to the specific communities within the contemplation of this legislation.

Art 3(1) of the 2009 Basic Regulation. In 2015 these provisions were revised and clarified further and the newly introduced art $3(1)$ (b) contemplates that 'the hunt is conducted for and contributes to the subsistence of the community, including in order to provide food and income to support life and sustainable livelihood, and is not conducted primarily for commercial reasons'. In a subtle variation to the initial 1983 Directive on harp and hooded seal pup products, art 3(1)(a) now refers to hunts that have 'traditionally been conducted by the community'. This phrasing does not specify that a hunt must exclusively use traditional methods, but instead requires a heritage of seal hunting and using the products for subsistence and small scale economic purposes.

Tamara Perišin, 'Is the EU Seal Products Regulation a Sealed Deal? EU and WTO Challenges' (2013) 62 International and Comparative Law Quarterly 373, 378.

In this regard, the terms of the UN Declaration on the Rights of Indigenous Peoples was considered particularly significant, as reflected in preambular recital (14) of Regulation 1007/2009. This issue is discussed further below.

36 Consolidated version of the Treaty on the Functioning of the European Union, [2012] oJ $\mathrm{C}_{326 / 47 .}$ 
In the light of this overarching objective, Regulation 737/1009 also recognizes seals as 'sentient beings that can experience pain, distress, fear and other forms of suffering'. ${ }^{38}$ Animal welfare concerns within the Regulation are accordingly centred on the 'pain, distress, fear and other forms of suffering which the killing and skinning of seals, as they are most frequently performed, cause to those animals'. ${ }^{39}$ This is deemed sufficiently serious as to necessitate 'action to reduce the demand leading to the marketing of seal products and, hence, the economic demand driving the commercial hunting of seals. ${ }^{\prime 0}$ While conceding that it 'might be possible' to kills seals in a manner that avoids unnecessary pain and suffering, the animal welfare dimension is considered by the Regulation to be so essential that underlying difficulties in ensuring compliance with these provisions require the draconian approach of preventing market access to most such products. ${ }^{41}$ Nevertheless, this tone appears to be at odds with other core elements of EU animal welfare legislation. While the offending killing methods are not expressly articulated within either the Basic Regulation or the Implementing Regulation, reference is made to the concerns of the Parliamentary Assembly of the Council of Europe, which called for a prohibition on cruel forms of killing, including the bludgeoning of seals. ${ }^{42}$ However, extensive EU provisions on animal welfare-which were adopted a mere eight days subsequent to the Basic Regulation-expressly endorsed the use of a 'percussive blow to the head' as a legitimate method of killing smaller

$38 \quad$ Preambular recital (1).

39 Preambular recital (4).

40 Preambular recital (10).

41 Preambular recital (11). As Fitzgerald observes, this contrasts unfavourably with the approach adopted by the Leghold Traps Regulation, which allowed for the trade in pelts taken by means that were compliant with more humane trapping standards. Notwithstanding concerns over the lack of consultation with interested parties, this legislation therefore operated in a more targeted manner by discouraging the use of particular traps deemed unacceptable by the EU authorities, without imposing a blanket ban on the marketing of fur products per se (and were therefore more likely to meet the wTO standards for the protection of public morals): Peter L. Fitzgerald, “Morality" May Not be Enough to Justify the EU Seal Products Ban: Animal Welfare Meets International Trade Law' (2011) 14 Journal of International Wildlife Law and Policy 85, 125-126.

42 Recommendation 1776 (2006) of 17 November 2006 on seal hunting. The primary concerns of the European Parliament, whose political input had a key role on the development of the EU Sea Regime, were largely confined to ensuring that seals were not skinned prior to death, as had been reported by a number of NGOs: Declaration of the European Parliament on banning seal products in the European Union [2006] oJ C 306E 194. 
species. ${ }^{43}$ Given the recognised sentience of all animals, neither provision explains precisely how animal welfare considerations render the bludgeoning of seals to be morally unacceptable, yet the same killing method as applied to a 'fur animal' below $5 \mathrm{~kg}$ in weight remains a valid activity, constrained only by a requirement not to despatch more than 70 individuals in such a manner in any given day. 44

Inconsistencies in the underlying application of animal welfare standards within the EU Seal Regime were compounded by procedural difficulties in implementing this legislation, since the practical conditions for applying the IC exception proved to be unduly burdensome in practice. While the Basic Regulation was generally supportive of Inuit enterprises, the initial Implementing Regulation introduced a series of administrative requirements that would prove to be difficult for a number of indigenous communities to meet. In particular, the authenticity of such products required verification from a 'recognized body', necessitating the creation of an attestation mechanism to ensure that such items are derived from genuine Inuit hunts and contribute to the subsistence of the community. As the Appellate Body observed, creating a 'recognized body' may entail significant burdens in some instances. ${ }^{45}$ As the report in EC-Seal Products clearly demonstrates, this was indeed the case for the Canadian Inuit who were unable to establish such an entity prior to the entry into force of the regime in 2010. Accordingly, Canadian Inuit sealers were precluded from exporting their products into the $\mathrm{EU}$, since they did not technically fulfill the criteria for applying the exception. The EU seal regime therefore resulted in the de facto exclusion of all Canadian seal products from the EU market, with commercial products expressly banned and the indigenous communities unable in practice to satisfy the requirements of the IC exception. Given the longstanding economic strength of EU-based fur traders, combined with the virtual lack of market disruption for Greenlandic communities, these provisions carried a discernible scent of protectionism, at least as far as the Canadian authorities were concerned. ${ }^{46}$

43 Council Regulation (EC) No 1099/2009 of 24 September 2009 on the protection of animals at the time of killing [2009] oJ L 303/1.

44 Regulation 1099/2009: Annex I, Chapter II, para. 3.

45 See wTo Appellate Body Reports: European Communities Measures Prohibiting the Importation and Marketing of Seal Products, wT/DS40o/AB/R (May 22, 2014) and European Communities Measures Prohibiting the Importation and Marketing of Seal Products, WT/DS401/AB/R (May 22, 2014) paras 5.337-5.338 ('EC-Seal Products').

$46 \quad$ Pirišin (n. 34) 378. 
The exclusion of Canadian seal products from the common market duly prompted two distinct strands of litigation. Firstly, Canadian Inuit interest groups, hunters' associations and individual hunters brought an action before the Court of Justice of the European Union (CJEU), in an attempt to force an annulment of the Seal Regime. ${ }^{47}$ In EU Seal Case I, Regulation 1007/2009 was challenged on several grounds, including that the regime violated the rights of indigenous peoples under international law. ${ }^{48}$ However, the case was rejected as inadmissible under art 263 TFEU. According to the General Court, the conditions incumbent in art 263(4), which govern the ability to bring an action for annulment, had not been met, since the contested regulation was not of 'direct and individual' concern to those raising the case. ${ }^{49}$ The fact that Canadian sealers were effectively barred from the EU market did not alter this restrictive interpretation of the conditions for the judicial review of these particular legal measures. On appeal, the ECJ confirmed that the action was inadmissible, and emphasized that 'the prohibition on the placing of seal products on the market laid down in the contested regulation is worded in general terms and applies indiscriminately to any trader falling within its scope..$^{50}$ Nevertheless, in the light of the recent decision by the wTо Appellate Body in EC-Seal Products analyzed below, the view of the European judiciary that the regulation applies indiscriminately must be regarded as flawed. Indeed, the Appellate Body would subsequently reject this interpretation and rule that Greenlandic and Canadian Inuit hunters had not been subject to equal treatment under the EU Seal Regime.

Whereas the actions in EU Seal Cases I and II were rejected as inadmissible, in Inuit Tapiriit Kanatami and Others $v$ European Commission (E U Seal Case III) the General Court decided to consider the substance of the claims brought

47 See Case T-18/10 Inuit Tapirit Kanatami and Others $v$ European Parliament and Council of the European Union ECR [2011] II-5599 [EU Seal Case I]. As outlined below, the case was then appealed, but subsequently rejected by the Court of Justice in Case C-583/11 Inuit Tapiriit Kanatami and Others $v$ European Parliament and Council of the European Union ECLI:EU:C:2013:625 [EU Seal Case II]. For a full analysis of these cases, see Martin Hennig, 'The Eu Seal Products Ban-Why Ineffective Animal Welfare Protection Cannot Justify Trade Restrictions under European and International Trade Law' (2015) 6 Arctic Review on Law and Politics 74 .

48 The compatibility of the EU Seal Regime with human rights norms addressing indigenous peoples is discussed further in section 2.2 below.

49 EU Seal Case I paras 68-92.

5o $\quad$ EU Seal Case II para. 73. 
by the litigants. ${ }^{51}$ In this third iteration of the litigation the General Court dismissed the action; the case was subsequently appealed for a final time to the Court of Justice. ${ }^{52}$ In the appeal, the appellants also sought the annulment of Regulation 1007/2009, but on the alternative basis that the contested measure had no legal foundation under the EU Treaties. Among the submissions made by the appellants, it was argued that the Eu had erred in adopting the contested Regulation under art 114 TFEU (ex. art 95 EC). This provision allows the EU legislators to adopt secondary legislative measures 'which have as their object the establishment and functioning of the internal market', a consideration that was repeatedly emphasized within the preambular paragraphs of the Regulation. ${ }^{53}$ With this in mind, the appellants contended that the primary objective of the regulation was clearly the protection of animal welfare, rather than seeking to improve the functioning of the internal market. ${ }^{54}$

The Court of Justice disagreed, however, and confirmed the finding of the General Court that the choice of legal basis for the regulation was correct. ${ }^{55}$ According to the General Court, it was clear from the Regulation itself that the principal objective of the measure was to improve the functioning of the internal market, rather than to advance the protection of animal welfare. ${ }^{56}$ The EU-wide ban on seal products would thereby remove national distinctions between the respective legal provisions governing the trade and marketing of seal products, which could otherwise have adversely affected the operation of the internal market. ${ }^{57}$ Furthermore, in the view of the General Court, the ban would ultimately prove beneficial since it would remove consumer hesitation towards buying common animal products that are not made from seals, but which might not be easily distinguishable from those that are, such as leather garments and Omega-3 capsules. ${ }^{58}$ These findings notwithstanding, which largely and uncritically echo the originally-stated rationale for the

51 Case T-526/10Inuit TapiriitKanatamiand Others $v$ European Commission ECLI:E U:T:2013:215 [EU Seal Case III]. To a considerable degree, the litigants of this action were the same as those in EU Seal Case II.

Case C-398/13 Inuit Tapiriit Kanatami and Others $v$ European Commission ECLI: EU:C:2015:535.

53 See especially preambular recitals (5), (6), (7), (8), (10), (12), (13), (15) and (21) of Regulation $737 / 2009$.

54 See Eu Seal Case III para. 26.

55 See Eu Seal Case IV para. 32.

56 Ibid., para. 36 .

$57 \quad$ Ibid., para. 38 .

$5^{8}$ Ibid., para. 39; see also Regulation 1007/2009, preambular recital (3). 
Regulation, ${ }^{59}$ the actual effectiveness of a general ban in dispelling or reducing consumer concerns over the presence of seal products within the internal market is highly questionable..$^{60}$ One important objection which can-and, indeed, should - be raised is the fact that any seal product that is approved under the IC exception may be freely sold throughout the entire EU internal market. Moreover by virtue of a free-trade clause, these provisions would in fact compel a Member State wishing to impose a national ban upon all seal products, irrespective of whether they are derived from either indigenous or 'commercial' hunts, to accept the import and sale of 'EU-approved' seal products permitted under the IC exception. In certain jurisdictions, such as those that had introduced domestic restrictions pre-dating the EU provisions, the IC exception may accordingly necessitate an unsolicited liberalization of national animal protection laws.

Thus far, the CJEU has rejected pleas for the annulment of the EU Seal Regime that have been submitted by Inuit interest groups and individual sealers. According to the Court, the legislation is in conformity with the broad tenets of EU law. Whereas the EU judiciary has been reluctant to annul the ban, external adjudicatory institutions have nonetheless stated unequivocally that the Seal Regime as it stood in 2009 was not in conformity with international trade law. In its May 2014 report to the EC-Seal Products case, the wTo Appellate Body found that these provisions violated the principle of non-discrimination. In this case, Canada and Norway claimed that the package of measures constituted a breach of WTо law and complaints were duly filed before the WTо dispute settlement system. The parties argued that the EU rules on seal products exercised an unjustified exclusionary effect upon Canadian and Norwegian seal products. One obvious inconsistency in the regime, as pointed out by the claimants, was the fact that Greenlandic seal products originating from Inuit hunts were granted access to the EU market under the IC exception, whereas seal products derived from hunts by the Canadian Inuit were denied entry. ${ }^{61}$

The wто Appellate Body confirmed that the regime was inconsistent with GATT art I:1 because it did not 'immediately and unconditionally' extend the same market access advantages to Canadian products as had been accorded to seal products originating from Greenland. ${ }^{62}$ The wTo Appellate Body affirmed that a trade ban on seal products could, in principle, be justified within the meaning of $\operatorname{art} \mathrm{Xx}(\mathrm{a})$ of the GATT 1994 as a measure 'necessary to

\footnotetext{
59 See especially preambular recital (3) of Regulation 737/2009 and n. 53 above.

6 See Hennig (n. 47) 78-79.

$61 \quad$ EC-Seal Products (n. 45) paras 5.329-5.332.

$62 \quad$ Ibid., para. 5.2.3.
} 
protect public morals'. However, in this particular case, the EU had failed to justify the unequal treatment of Greenlandic Inuit products, which were marketable in the EU under this exemption, and those of the Canadian Inuit, which were classified as prohibited products deriving from 'commercial' hunts and were therefore banned. ${ }^{63}$ The Appellate Body further noted that the IC exception constituted a significant derogation to the ban, and that the Eu had failed to demonstrate how the discrimination resulting from the manner in which the EU Seal Regime treats IC hunts as compared to "commercial" hunts can be reconciled with, or is related to, the policy objective of addressing EU public moral concerns regarding seal welfare. ${ }^{64}$ In other words, the generous IC exemption granted solely to Greenlandic Inuit products could not be logically based on the objective of improving animal welfare conditions.

Further, the Appellate Body stressed that the IC exception was in essence available exclusively to Greenland, creating a discriminatory effect between countries in which essentially the same conditions prevail. ${ }^{65}$ The EU argued that it had engaged in "multiple efforts" to assist the Inuit in Canada to benefit from the IC exception, ${ }^{\prime} 6$ although the Wто Appellate Body was not convinced that it had made 'comparable efforts' to those made with respect to the Greenlandic Inuit. ${ }^{67}$ In this regard, as noted above, it was emphasized that one important flaw in the EU Seal Regime was the requirement for access to the IC exception to be dependent upon the establishment of a 'recognized body', which is to be responsible inter alia for verifying that seal products originate from genuine Inuit hunts.

In the wake of the report of the WTO Appellate Body, the Eu has made considerable adjustments to the Seal Regime in order to address the elements that were considered to have contravened wTO law, while seeking to preserve its underlying features. In an attempt to reconcile the IC exception with the overarching EU policy objective of addressing public concerns regarding seal welfare, the Basic Regulation has been substantively amended. Thus in the reformed Regulation 2015/1775, the new art 3(1)(c) provides that Inuit seal products can now only be placed on the EU market if 'the hunt is conducted in a manner which has due regard to animal welfare, taking into consideration the way of life of the community and the subsistence purpose of the hunt.'

\footnotetext{
$63 \quad$ Ibid., para. 5.3.3.3.

64 Ibid., para. 5.320.

65 Ibid., para. 5.333.

$66 \quad$ Ibid., para. 5.337.

$67 \quad$ Ibid., para. 5.337.
} 
Besides addressing those aspects of the legislation that were considered to have contravened the WTO Rules, the Eu has also engaged with the Canadian and Inuit authorities in order to facilitate the establishment of an attestation mechanism, which will, once again, allow the Canadian Inuit to export seal products into the EU market. ${ }^{68}$ More specifically, since 30 July 2015 the Government of Nunavut has been recognized as an attestation body qualified to certify Inuit seal products under EU Seal Regime, ${ }^{69}$ thereby facilitating future trading and export opportunities within the common market.

It is certainly an encouraging sign towards future compliance with international trade law that the EU has taken such steps towards addressing the discriminatory features of the Seal Regime. Nevertheless, it remains questionable whether these legislative amendments and the subsequent re-engagement with the Canadian and Inuit authorities can rectify the damage that has been done to the economic interests of the Canadian Inuit sealing community. As observed by Canada in the course of the proceedings before the wTо dispute settlement system, the ban has already taken a heavy economic and social toll on the Inuit community:

The effect of the EU Seal Regime is to exclude from the EU market all seal products derived from seals killed in commercial hunts, regardless of whether they were harvested humanely. In doing so, the EU Seal Regime has effectively shut out Canadian seal products from the EU market. The negative economic impacts of this measure have reverberated through coastal communities in the Canadian Maritimes, where economic opportunities are limited, and in Canada's Inuit communities, where the Inuit have historically relied on the income generated from seal skin sales to supplement their subsistence-oriented lives. ${ }^{70}$

Thus, in light of the legal amendments and the inclusion of the Nunavut Government as an attestation body, the EU is now convinced that the current Seal Regime is in compliance with wTo law. ${ }^{71}$ This may very well be the

68 See Status Report Regarding Implementation of the DSB Recommendations and Rulings in the Dispute European Communities-Measures Prohibiting the Importation and Marketing of Seal Products (WT/DS400 and WT/DS401), 16 October 2015.

69 See Commission Decision of 26 October 2015 recognising the Department of Environment, Government of Nunavut in accordance with Article 3 of Implementing Regulation (EU) 2015/1850 laying down detailed rules for the implementation of Regulation (EC) No $1007 / 2009$ of the European Parliament and of the Council on trade in seal products, C (2015) 7273 final (art 1).

70 See the Integrated executive summary of Canada, in European Communities-Measures Prohibiting the Importation and Marketing of Seal Products, Reports of the Panel, wT/ DS40o/R, WT/DS401/R, Addendum, Annex B-1, 25 November 2013, para. 2.

71 Status Report (n. 68). 
case in principle. However, as noted in section 2.2 below, it may be questioned whether the amended regime does indeed strike a fair balance between the protection of animal welfare and the protection of the human rights of indigenous peoples.

\subsection{Animal Welfare v. the Human Rights of Indigenous Peoples}

In light of the report of the wTO Appellate Body in EC-Seal Products, which objectively revealed the discriminatory features of the EU Seal Regime, it is clear that this package of European measures has largely failed to effectively reconcile the protection of animal welfare and the human rights of indigenous peoples. As regards animal welfare protection, the current regime still allows for the unrestricted marketing of seal products that fall within the scope of the IC exception, and the generosity of the exemption neither eliminates nor efficiently reduces consumer fears over the availability of allegedly undesirable seal products within the internal market, which had been a primary intention of the legislation in the first place. Similarly, in terms of protecting the human rights of indigenous peoples, the regime has thus far served only to promote the unlawful exclusion of Canadian Inuit hunters from the EU market. It is also questionable whether the Canadian Inuit seal products will ultimately be able to re-enter the EU market in a meaningful economic sense. Not only have prices for seal products plummeted in the wake of this legislation, ${ }^{72}$ but market realities have also materially changed. Ironically, given that a central motivation of the EU Seal Regime was to constrain the activities of commercial operators, a particular problem presently confronting Inuit hunters is the absence of a large scale commercial seal industry in Canada. Prior to the introduction of the EU restrictions, the Canadian Inuit were reliant upon synergies with commercial producers in order to export their products to the EU. ${ }^{73}$ The disappearance of large-scale producers has therefore inhibited such mutually-supportive logistical collaborations with commercial operators and could negate the economic viability of Inuit hunts. ${ }^{74}$

It is striking that prior to the ruling of the Wто Appellate Body, the EU did not undertake a more thorough evaluation of the possibility that the fundamental rights of indigenous peoples caught by the terms of the Seal Regime

72 The market value for sealskin decreased by over $50 \%$ within a year of the entry into force of Regulation 1007/2009, despite a significant reduction in the numbers of individuals harvested: Nikolas Sellheim, 'The Goals of the EU Seal Products Trade Regulation: From Effectiveness to Consequence' (2015) 51 Polar Record 274, 284.

73 EC-Seal Products (n. 45) para. 5.334.

74 See Government of Nunavut, Report on the Impacts of the European Union Seal Ban, (EC) No 1007/2009, (Nunavut, Iqualit, 2012) 9. 
might be violated in the process of protecting animal welfare. Indeed, as observed by Hossain, a strong case can be made that the regime had undermined the human rights of Canadian Inuit sealers since its inception in 2009. ${ }^{75}$ Of particular significance in this regard is art 27 of the International Covenant on Civil and Political Rights (ICCPR), which guarantees the religious, linguistic and cultural rights of minority groups: ${ }^{76}$

[i]n those States in which ethnic, religious or linguistic minorities exist, persons belonging to such minorities shall not be denied the right, in community with the other members of their group, to enjoy their own culture, to profess and practice their own religion, or to use their own language.

The notion of a 'minority' is not defined in the ICC PR. Nevertheless, as Hossain considers, it is 'nonetheless a fact that indigenous peoples mostly comprise small minorities except only in a few countries in which they form a majority. ${ }^{\prime 7}$ Thus, minority groups like the Canadian Inuit—and, indeed, Greenlanders ${ }^{78}$ should therefore fall within the scope of art 27. Furthermore, the UN Human Rights Committee has emphasized in a general comment to this particular provision that the term "culture" includes the particular ways of life of minority communities, such as hunting and fishing. ${ }^{79}$ Moreover, in Länsman $v$ Finland, the Human Rights Committee established that art 27 ICCPR requires that members of a minority shall not be 'denied' the right to enjoy his or her

75 Kamrul Hossain, 'The EU Ban on the Import of Seal Products and the WTO Regulations: Neglected Human Rights of the Arctic Indigenous Peoples?' (2013) 49 Polar Record 154, 163-164.

76 International Covenant on Civil and Political Rights, adopted and opened for signature, ratification and accession by General Assembly Resolution 2200 A (XXI) of 16 December 1966; 999 UNTS 171.

77 Hossein (n. 75), 161.

78 It would appear that the Greenlandic Inuit are also protected by art 27 ICCPR. Whereas the Inuit of Greenland constitute a majority of the population within Greenland itself, the territory of Greenland is still far from an independent entity. In recent years, while Greenland has attained a marked degree of autonomy from Denmark it is not yet a fully autonomous state. From this perspective, the Greenlandic Inuit can be considered to constitute a minority of the Danish population and should therefore continue to fall within the scope of art 27 ratione personae.

79 Human Rights Committee, General Comment 23, art 27 (Fiftieth session, 1994), Compilation of General Comments and General Recommendations Adopted by Human Rights Treaty Bodies, U.N. Doc. HRI/GEN/1/Rev.9 (Vol. I), p. 209. 
culture. ${ }^{80}$ It is certainly debatable whether the EU seal products ban serves to deny outright the Canadian Inuit the right to enjoy their culture. Likewise, due to their inherently cumulative and subjective nature, it is difficult to establish definitively that the collapse of the sealing industry directly triggered a spate of social malaises within indigenous communities that would amount to a violation of this provision. Indeed, as Sellheim observes, 'it may be difficult to provide satisfactory legal evidence that the seal products ban adversely affects Inuit culture. ${ }^{81}$ Nevertheless, the discriminatory aspects of the Eu Seal Regime, combined with the significant economic losses that market restrictions have inflicted upon such communities, clearly indicate that this legislation presents scope for conflict with the broad spirit—if not necessarily the strict letterof art 27 .

As a concluding remark, it is apparent that the current EU Seal Regime has proved to be insufficient in terms of protecting both animal welfare rights and the fundamental human rights of indigenous peoples, which in this case stand out as conflicting objectives. Consequently, it remains to be seen how the EU plans to make reparations for the financial injustice suffered by Canadian Inuit sealers. A mere re-establishment of EU market access is not, in and of itself, sufficient to remedy this five-year exclusion from the market, which has had a dire negative economic impact upon Canadian Inuit sealers.

\section{3}

Whaling in the Arctic

As with the hunting of seals, the harvesting of cetaceans by the indigenous peoples of the High North has occurred since the commencement of human settlement in the Arctic. Archaeological evidence suggests that Alaskan whaling may date back as far as 8000 years, ${ }^{82}$ while whaling activities in the Canadian Arctic are known to have occurred over the course of 3000 years. ${ }^{83}$ Hunting in Greenland may be traced back to $2400 \mathrm{BC}^{, 84}$ while whaling and

8 o Human Rights Committee Jouni E. Länsman et al. v Finland, Communication No. 671/1995, U.N. Doc. CCPR/C/58/D/671/1995 (1996).

$81 \quad$ Sellheim (n. 72$) 281$.

82 International Whaling Commission, Aboriginal/Subsistence Whaling (With Special Reference to Alaska and Greenland Fisheries) (Cambridge, IWC, 1982) 36.

83 G.G. Monks, 'Quit Blubbering: An Examination of Nuu'chah'nulth (Nootkan) Whale Butchery' (2001) 11 International Journal of Osteoarchaeology 136.

84 Richard A. Caulfield, Greenlanders, Whales and Whaling: Sustainability and SelfDetermination in the Arctic (Hanover, University Press of New England, 1997) 81. 
sealing have been continuously conducted by Greenlanders since at least 1050 AD with the settlement of the island by the Thule Inuit. ${ }^{85}$ Indigenous hunting therefore significantly pre-dates what has since been identified as the first systematic commercial harvesting activities of the Eleventh Century and the later advent of the era of modern whaling. ${ }^{86}$ This long-standing and unbroken heritage of the consumption of marine mammals remains highly significant to many Arctic indigenous communities. Participation in hunting activities confers social status within the community, while the fruits of these labours represent an improtant source of nutrition in a challenging living environment, as well as a key element of the Inuit identity. Indeed, in many such communities 'true' Inuit status is often connected to the consumption of traditional food sources, ${ }^{87}$ notably whales and seals, which are distinguished from 'white man's foods' to which non-wild caught products (and their consumers) are derogatorily referred. ${ }^{88}$

The continued harvesting of whales by Arctic indigenous communities gives rise to the same regulatory dichotomy encountered by the $\mathrm{EU}$ in the context of seal hunting: there remains considerable popular support and sympathy for the cultural and nutritional needs of the Inuit, notwithstanding trenchant opposition from the EU institutions and the vast majority of the Member States to the killing of cetaceans. As with the seal provisions, the EU has actively opposed commercial harvesting and, as outlined in section 3.1 below, imposed heavy restrictions upon the marketing of cetacean products within the internal market, subject to limited exemptions for items intended for noncommercial purposes. This specific legislation has generally avoided the opprobrium associated with the EU Seal Regime. Instead, as discussed in section 3.2, the primary legal issues raised by the convergence of the stated $\mathrm{EU}$ position towards cetaceans and the interests of indigenous peoples in harvesting whales have involved the multilateral regulation of marine mammals. To this end, the collective negotiating positon adopted by the EU towards subsistence whaling represents an intriguing case-study of its approach to key

85 Ibid., 26.

86 The first coordinated attempts at commercial whaling commenced in the Basque region of Northern Spain. Modern whaling is considered to have commenced in the 186os with the introduction of the exploding harpoon: J.N. Tønnessen and A.O. Johnsen, The History of Modern Whaling (London, C Hurst \& Co, 1982) 3.

87 Wenzel (n. 16) 139 .

88 Richard A. Caulfield, 'Aboriginal Subsistence Whaling in West Greenland' in Milton M.R. Freeman and Urs P. Kreuter (eds) Elephants and Whales: Resources for Whom? (Amsterdam, Gordon and Breach, 1994) 261, 282. 
Arctic-centric issues within pertinent international for a, as clearly envisaged within the 2016 Arctic Policy Statement. ${ }^{89}$

\subsection{The Regulation of Cetacean Products under E L Law}

As with the corresponding seal provisions outlined above, specific measures have been introduced by the $\mathrm{EU}$ to restrict the market presence of cetacean products, which were also largely inspired by popular and institutional opposition to the hunting of whales. Like the EU seal regime, these measures were largely intended to undermine the global market for commercially-derived cetacean products, while simultaneously seeking to preserve the long-standing subsistence hunting entitlements of recognised indigenous communities. The EU cetacean provisions encompass two complementary yet relatively overlooked measures adopted in 1981, namely Regulation $348 / 81^{90}$ and its implementing legislation, Regulation 3786/81. ${ }^{91}$ Regulation 348/81 emerged from the somewhat unexpected context of industrial restrictions upon leather tanning, instituted by the incoming Thatcher administration in the UK in 1979. At the material time, domestic restrictions had been imposed upon the importation of whale products by a number of EU Member States, with the general exception of sperm whale oil, which was still used in a dwindling number of industrial processes. In 1979, proposals for a full moratorium on sperm whaling were narrowly defeated within the global regulatory body, the Iwc. ${ }^{92}$ These developments nevertheless prompted the UK authorities to immediately lobby for Community-wide restrictions on the importation of whale oil and derivative items. ${ }^{93}$ While partly a manifestation of governmental opposition to the

\footnotetext{
89 Arctic Policy Statement (n. 2) 7.

90 Council Regulation (EEC) No. 348/81 of 20 January 1981 on common rules for imports of whales or other cetacean products [1981] Official Journal L39/1.

91 Commission Regulation (EEC) No. 3786/81 of 22 December 1981 laying down provisions for the implementation of the common rules for imports of whale or other cetacean products [1981] Official Journal L377/42.

92 On these endeavours see Patricia Birnie, 'The Role of Developing Countries in Nudging the International Whaling Commission from Regulating Whaling to Encouraging Nonconsumptive Uses of Whales' (1985) 12 Ecology Law Quarterly 937, 957-959. A moratorium on sperm whaling was eventually adopted at the Thirty-Third Meeting of the IWC in 1981, with this motion co-sponsored by France, the Netherlands and the UK, acting in their capacity as independent contracting parties in the absence of an allied EEC negotiating positon.

Anonymous, 'UK Harpoons Whalers', New Scientist, 12 July 197985.
} 
commercial harvesting of whales, ${ }^{94}$ these entreaties were also motivated by concerns that the increasingly stringent national constraints on cetacean products could exert a potentially distortionary effect upon the national leather industry, since sperm whale oil was still used to a significant degree by rival producers, for which domestic manufacturers 'rightly feared that its hardpressed industry could experience unfair competition from non-Community countries. ${ }^{95}$

Such calls would ultimately find fertile ground within the institutions of the European Economic Community (EEC), with whale conservation occupying a position of some significance upon its operational agenda. In November 1980, both the Commission and the European Parliament considered this issue in considerable depth, advocating legislation to restrict the commercial use of cetacean products, albeit with differing approaches. The Commission proposed a general ban on the importation of whale meat, as well as products that had been treated with whale oil. ${ }^{96}$ Meanwhile, in a more extensive intervention, the Parliament called not only for a ban on 'all products which can be shown to derive from cetaceans or to contain products derived from cetaceans' but for the EEC and its Member States to formally pursue a moratorium upon commercial whaling within the IwC. ${ }^{97}$ Although a number of Member States would eventually play a significant role in securing a moratorium on commercial hunting at the IWC's historic Thirty-Fourth Meeting in $1982,{ }^{98}$ the EEC ultimately favoured the more targeted proposal of the Commission and confined its policies towards whaling to the specific arena of international trade.

94 On the growing opposition in Europe to commercial whaling since the 196os see Charlotte Epstein, The Power of Words in International Relations: Birth of An Anti-Whaling Discourse (Cambridge, Massachusetts, MIT Press, 2008) 258-259.

95 House of Commons Debate, 8 December 1980, Hansard, Vol. 995 cc.721, 722.

96 сом (80) 788 .

97 Resolution Embodying the Opinion of the European Parliament on the Proposal from the Commission of the European Communities and the Council for a Regulation on Common Rules for Imports of Whale Products [1980] oj C 291/49.

98 At this juncture, paragraph $10(\mathrm{e})$ of the Schedule to the International Convention for the Regulation of Whaling 161 UNTS 72 (ICRW) was famously amended so as to set commercial catch limits at zero, a position that may subsequently be amended by a threequarters majority of the contracting parties present and voting, although the stated positon against whaling by a significant majority of the parties renders this a remote prospect at present. On the events of the Meeting and voting patterns towards this historic proposal see Patricia Birnie, 'Countdown to Zero' (1983) 7 Marine Policy 68. 
To this end, Regulation 348/81 established that the importation of a relatively small and specific set of items, listed on an Annex to the provision and including meat, offal, fats, oils and products treated with cetacean oil, would from 1 January 1982 require an import licence ${ }^{99}$ to be overseen by a Committee on Cetacean Products. ${ }^{100}$ Although Regulation 348/81 was initially requested as a means of stabilising market conditions for cetacean products, this provision was ultimately adopted on explicitly environmental grounds. Indeed, the preamble observes that trade restrictions are an inevitable consequence of the need to ensure the 'conservation of cetacean species'. Moreover, legal concerns had initially been raised over the UK's proposals as to whether any future measures could be adopted pursuant to the EEC's then nascent fisheries competences, as had been favoured by a considerable majority of the Member States at the time. Strong opposition to this approach from Denmark and Germany meant that Regulation 348/81 was ultimately adopted under the auspices of what was previously art 235 of the EEC Treaty (now art 352 TFEU) and was hence a measure of broader environmental law, rather than a fisheries matter. ${ }^{101}$ Unlike the various provisions addressing seal products, Regulation $348 / 81$ makes no reference to the Inuit or the exigencies of indigenous subsistence hunting. Accordingly, this provision authorises the trade in Inuit-derived items essentially by default, with import restrictions applying solely to 'products to be used for commercial purposes.' ${ }^{102}$ Instead, as outlined further in section 3.2.2 below, the position of traditional subsistence users of cetacean products - specifically in the context of Greenlanders-is addressed more comprehensively under legislation intended to give effect to commitments

99 Art 1(1). Under art 3 the Council may amend the Annex following a qualified majority vote, with individual Member States permitted to ban additional products pending such a decision; this process has not occurred to date. Conditions for the practical operation of import licenses were subsequently established under Regulation 3786/81.

100 Art 2(1). The work of the Committee has remained generally obscure, with the sole reference to its activities arising in response to a question from the European Parliament in 1982, in which it was recommended that the Annex of products subject to the controls of Regulation 348/81 ought not to be extended until the provision had been in force for a longer period of time: [1982] oJ C 218. The cetacean provisions therefore offer few obvious lines of comparison with the 'recognised body' for attestation envisaged under the amended Eu legislation on seal products.

101 A.M. Farmer (ed) Manual of European Environmental Policy (London, Routledge, 2012) 9.12. This appears to have been a source of frustration to the UK government, which saw this wrangling as delaying the regulation of its original market-related concerns (n. 95) 723 .

$102 \operatorname{Art} 1(1)$. 
pursuant to the Convention on International Trade in Endangered Species of Wild Fauna and Flora 1973 (CITES). ${ }^{103}$ Indeed, the preambular intentions of Regulation 348/81 identify this provision as a temporary measure pending the adoption of more general legislation on the trade in endangered species, hence whale products might have been eventually expected to have been addressed holistically in the context of CITES commitments. Nevertheless, Regulation 348/81 was not ultimately repealed by the first EU CITES Regulation in $1982,{ }^{104}$ nor indeed has it been explicitly subsumed into any of the successive iterations of this legislation, hence it remains the primary regulatory regime for such products vis-à-vis the internal market.

The restrictions upon the trade in cetacean products intended for commercial use established under Regulation 348/81 have also been bolstered to some extent by the application of the Habitats Directive, ${ }^{105}$ the cornerstone provision of EU nature conservation law. Under the Directive, the Member States adopt a two-pronged approach to the conservation of threatened species. In the first instance, Member States are obliged to identify and, in tandem with the EU institutions, designate Special Areas of Conservation (SACs) for species of community importance. ${ }^{106}$ Moreover, the Habitats Directive mandates that Member States 'shall take the requisite measures to establish a system of strict protection for the animal species listed in $\operatorname{Annex~} \operatorname{IV}(\mathrm{a})$ in their natural range'.107 At present, 'all species' of cetaceans have been so listed, but only one seal species. Thus, under the system of strict protection envisaged by the Directive, art 12(1) prohibits inter alia all forms of deliberate capture or killing of cetaceans in the wild. While this provision has obstructed the commercial whaling aspirations of potential new Arctic EU Member States, there is nonetheless scope for subsistence whaling by recognised indigenous communities to be permitted under the Directive. In this respect, art 16(1)(e) allows for the taking of Annex IV(a) species 'under strictly supervised conditions, on a selective basis and to a limited extent ... in limited numbers specified by the competent national authorities'. Although untested in this context, and contingent upon

\footnotetext{
103993 UNTS 243.

104 Council Regulation (EEC) No $3626 / 82$ of 3 December 1982 on the implementation in the Community of the Convention on international trade in endangered species of wild fauna and flora [1982] oJ L 384/1 (subsequently repealed).

105 Council Directive 92/43/EEC of 21 May 1992 on the conservation of natural habitats of wild fauna and flora [1992] OJ L 206/7.

106 These species are listed on Annex II to the Directive. From the standpoint of marine mammals, these specific obligations apply solely to harbour porpoises and bottlenose dolphins, as well as grey and harbour seals.

107 Art 12(1).
} 
the support of both a sponsoring Member State and the European Commission, this derogation could serve to reconcile broad EU support for the subsistence and cultural needs of indigenous peoples with the core conservation objectives advanced by the Directive.

At present, however, the Habitats Directive has no application to the marine Arctic, since its scope is restricted to the European territory of the Member States'. ${ }^{108}$ Accordingly it does not apply to whales taken in the jurisdictional waters of Greenland, which formally left the EEC in January $1985,{ }^{109}$ or Arctic whaling states such as Norway and Iceland, which have rejected the prospect of EU membership in national referenda, with the uncompromising stance of the Commission towards commercial whaling recognised as a key factor in this regard. ${ }^{110}$ Nevertheless, from a trade perspective, these provisions may still exert an influence upon the eventual fate of species harvested beyond its jurisdictional reach, since art 12(2) prohibits the keeping, transport, sale or exchange or offering for sale or exchange of 'specimens taken from the wild.'111 Specimens are defined in $\operatorname{art} 1(\mathrm{~m})$ of the Directive as:

108 Art 2(1). This term gave rise to considerable confusion and the initial transposing legislation of a number of Member States applied the Directive solely to the territorial sea, hence for highly mobile species such as marine mammals, the Directive was initially considered to be of limited value. The ECJ subsequently confirmed the application of the Directive to the full range of jurisdictional waters in Commission v UK [2005] ECR I-9017 (para. 117). On the jurisdictional scope of the Directive see Richard Caddell, 'The Maritime Dimensions of the Habitats Directive: Past Challenges and Future Opportunities' in Gregory Jones QC (ed) The Habitats Directive: A Developer's Obstacle Course? (Oxford, Hart, 2012) 183, 187-189.

109 Treaty, amending with regard to Greenland, the Treaties establishing the European Communities [1985] OJ L 29/1. See also Council Decision 2014/137/E U of 14 March 2014 on relations between the European Union on the one hand, and Greenland and the Kingdom of Denmark on the other [2014] oJ L 76/1.

110 On the role of whaling in the Norwegian referendum see Steinar Andresen, 'The Making and Implementation of Whaling Policies: Does Participation Make a Difference?' in David G. Victor, Kal Raustiala and Eugene B. Skolnikoff (eds), The Implementation and Effectiveness of International Environmental Agreements: Theory and Practice (Cambridge, Massachusetts, MIT Press, 1998) 431, 455-456. On the whaling aspects of the Icelandic accession negotiations see Peter Davies, 'Iceland and European Union Accession: The Whaling Issue' (2011) 24 Georgetown International Environmental Law Review 23.

111 Art 12(2) applies only to animals taken after the entry into force of the Directive, thereby allowing free trade in pre-existing products, most notably on the lucrative antiquities market. Items taken after this period remain subject to regulation under CiTEs which, as discussed in section 3.2.2, has generated sporadic controversies over products derived from narwhal tusks. 
any animal or plant, whether alive or dead, of the species listed in Annex IV and Annex V, any part or derivative thereof, as well as any other goods which appear, from an accompanying document, the packaging or a mark or label, or from any other circumstances, to be parts or derivatives of animals or plants of those species.

This definition serves to further restrict the importation of whale products into the EU, which thereby 'diminishes a potential loophole, namely that the prohibition on the killing of animals outside Community waters is not provided for in the Habitats Directive.'112 Thus, while the Habitats Directive itself offers no formal protection to marine mammals outside EU waters, it does prevent the importation into the internal market of products derived from hunts conducted beyond the physical boundaries of the $\mathrm{EU}$.

In contrast to the $\mathrm{EU}$ seal provisions, import restrictions on cetacean products have proved to be relatively uncontroversial. No specific litigation has been generated under these auspices, nor has there been any meaningful assertion of cultural injury or unfair treatment sustained by any indigenous constituency. This may be attributed to three key factors that did not arise in the context of the Eu's seal regime. In the first instance, Regulation 348/81 coincided with a precipitous decline in the demand for whale products, for both economic and ecological reasons. At the material time, cheaper alternatives to baleen whale oil were being developed by manufacturers, a process that was somewhat accelerated by the IWC's graduated restrictions on commercial whaling that rendered sourcing this product increasingly cost-prohibitive. ${ }^{113}$ Allied to this, a concerted environmental lobby helped to steer consumer demand towards alternative oils as an essential component in industrial manufacturing and, in particular, domestic products. ${ }^{114}$ Accordingly, Regulation $348 / 81$ has addressed a niche market within the $\mathrm{EU}$ of products that are essentially

112 Peter G.G. Davies, 'The Legality of Norwegian Commercial Whaling under the Whaling Convention and its Compatibility with European Community Law' (1994) 43 International and Comparative Law Quarterly 270, 281 (original emphasis).

113 On this process see Heidi Scott, 'Whale Oil Culture, Consumerism and Modern Ecology' in Ross Barrett and Daniel Worden (eds) Oil Culture (Minneapolis, University of Minnesota Press, 2014) 3 .

114 In the $\mathrm{UK}$, for example, retailers of leather goods came under increasing pressure to discontinue the use of whale oil: 'UK Harpoons Whalers' (n. 93) 85. There is also clear evidence that consumer concerns were shared by a number of Parliamentarians, with strong opposition within the House of Commons to the continued use of any whale products in the UK (n. 95) 724. This was a microcosm of a wider global movement to eschew whale products: see further Epstein (n. 94) 87-164. 
marketed to the Inuit diaspora and does not generate the same economic repercussions encountered by the sealing industry with its wider array of potential consumers. Second, the cetacean provisions were unencumbered by the problematic administrative requirements established under the later seal provisions and did not therefore discriminate between importers of noncommercial products in a manner that would disrupt market access by particular communities. Third, and perhaps most significant, the EU provisions on cetacean products have essentially reflected trade entitlements that have been established on a multilateral basis and are widely accepted as a legitimate special case by the international community. Indeed, unlike seals, for which the emergence of a circumpolar supervisory body remains an unlikely prospect, the volume of indigenous whaling in any given season has been largely predetermined by a recognised global regulatory institution. While this process has generated increasing consternation among particular states in recent years, as outlined below, its outcomes have nonetheless been faithfully implemented in a non-discriminatory manner by the EU through these provisions.

\subsection{The $E U$ and the Multilateral Regulation of Cetaceans in the Arctic}

In addition to the regulatory challenges experienced in the development of internal legislation to address marine mammal products, another key objective of the EU in its engagement with the Arctic - the enhancement of multilateral governance for this region through pertinent multilateral fora-also invites further scrutiny in the specific context of marine mammals. In the 2008 Joint Communication, this was identified as one of the three main policy priorities for the EU vis-à-vis the Arctic, ${ }^{115}$ which sought to facilitate the 'full implementation of already existing obligations' within relevant regulatory frameworks. ${ }^{116}$ These aspirations were expressed in somewhat more detail in the recent Arctic Policy Statement of April 2016, in which it was considered that the EU 'should continue its engagement in multilateral environmental agreements that also have particular relevance to the Arctic, and encourage their implementation.'117 The earlier Joint Communication provided little indication of the specific fora through which this mandate was considered best pursued. However, while neither document expressly referred to marine mammals as such, the 2016 Statement nonetheless identified particular organizations of significance, which might therefore be considered operative priorities for the EU institutions in their external dealings. These include a number of regimes with a clear

\footnotetext{
115 Joint Communication (n. 1) 3.

116 Ibid., 10.

117 Arctic Policy Statement (n. 2) 7.
} 
relevance to cetaceans and the hunting activities of Arctic indigenous peoples, notably the ICRW and CITES. To this end, in engaging with these particular fora, the EU intends to take an 'active negotiating position ... to encourage all countries and regions to assume their responsibilities'.118

As a negotiating bloc of contracting parties to a particular treaty, the EU can wield considerable power within multilateral organizations, ${ }^{119}$ even those with an extensive cohort of participants. Therefore, from the perspective of Arctic indigenous peoples seeking to secure particular entitlements within such bodies, the EU may constitute a significant ally—or a formidable opponent. In this regard, the sustainable use of cetaceans by indigenous communities presents an illuminating case-study of the implementation of the EU's partnership objectives, engaging three separate regimes in the form of the IWC, Cites and the North Atlantic Marine Mammal Commission (NAMmCO). As this section demonstrates, a review of collective practices towards the issue of indigenous whaling reveals that the EU has generally proved to be a supportive partner to indigenous communities in promoting subsistence hunting activities, notwithstanding its wider objectives in opposing the commercial exploitation of marine mammals. Nevertheless, this support is not unqualified and the EU has also opposed indigenous demands and insisted upon stricter controls over these activities where concerns have arisen over the conservation status of particular species. Moreover, the EU has steadfastly avoided active engagement with NAMMCO, the regional regulator charged with the oversight of the sustainable use of marine mammals in the Arctic, further highlighting the complexities that this particular issue poses for EU policies towards the High North.

\subsubsection{Qualified Support: The EU and the IWC}

On a multilateral level, whaling in the Arctic is regulated predominantly under the auspices of the ICRW and, more specifically, its constituent management body, the IWC. Inaugurated in 1949 to facilitate the stated objectives of the ICRW 'to provide for the proper conservation of whale stocks and thus make possible the orderly development of the whaling industry'120 the IWC has become an increasingly fractious institution as public and governmental attitudes towards the continued commercial hunting of whales has become

\footnotetext{
118 Ibid., 14.

119 For an illuminating discussion of the collective bargaining of the EU in particular regimes see Tom Delreux, The EU as an International Environmental Negotiator (Farnham, Ashgate, 2011) 61-134.

120 Preamble to the ICRW.
} 
steadily more polarised. ${ }^{121}$ As observed above, in 1982 the IWC imposed a moratorium on the commercial hunting of whales. A considerable degree of whaling has nonetheless continued within the Arctic, pursuant to objections or reservations entered against the commercial moratorium, ${ }^{122}$ for scientific purposes as provided under Article VIII of the IC RW ${ }^{123}$ and, most pertinently from the perspective of Arctic indigenous communities, under a recognised exemption 'to satisfy aboriginal subsistence need.' ${ }^{124}$

The aboriginal subsistence exception has been a long-standing feature of multilateral whaling governance, having been introduced in the first global treaty to regulate whaling in $1931 .{ }^{125}$ Although absent from subsequent arrangements, ${ }^{126}$ it was reinstated within the ICRW Schedule in 1946 following a proposal by the USSR in respect of its indigenous Chukotkan communities. ${ }^{127}$ Since 1950 , the aboriginal subsistence provisions of the

121 There is a voluminous literature on the travails of the IWC and the processes by which this organisation has become steadily more beleagured, hence constraints of focus and space necessaitate a peripheral treatment of these issues in this Chapter. Nevertheless, as noted below, the febrile atmosphere within the IWC has impacted to a degree upon negotiations for subsistence quotas for Arctic indigenous communities. For a thorough discussion of the IWC generally see Malgosia Fitzmaurice, Whaling and International Law (Cambridge, Cambridge University Press, 2015) 29-121; the emergence of a sustained anti-whaling agenda and its repercussions for multilateral management are outlined comprehensively by Epsetin (n. 94) 87-163 and Sarah Suhre, 'Misguided Morality: The Repercussions of the International Whaling Commission's Shift from a Policy of Regulation to One of Preservation' (1999) 12 Georgetown International Environmental Law Review 305 .

122 Norway entered an immediate objection to the moratorium and has continued to conduct commercial whaling activities in the Arctic. Iceland withdrew from the Convention in 1991 and rejoined in 2002, subject to a contentious reservation to the moratorium: see further Alexander Gillespie, 'Iceland's Reservation at the International Whaling Commission' (2003) 14 European Journal of International Law 977.

123 A limited degree of scientific whaling has been conducted by Iceland, although little research whaling has occurred in the Arctic in recent years. The scientific research exemption has been primarily_ and contentiously_invoked by Japan, which the Internatonal Court of Justice recently considered to have fallen short of the standards required of Article virI: Case Concerning Whaling in the Antarctic (Australia v. Japan; New Zealand Intervening); Judgment of 31 March 2014.

124 Section 13 of the ICRW Schedule.

125 Convention for the Regulation of Whaling 1931; 155 LNTS 349. Art 3 prescribed specific entitlements for 'aborigines dwelling on the coasts of the territories of the High Contracting Parties'.

126 International Agreement for the Regulation of Whaling 1937; 190 LNTS 79.

127 Resolution 10 of the 1946 International Whaling Conference. 
ICRW Schedule have been successively expanded and amended to establish particular tribal requirements and restrictions on certain stocks. ${ }^{128}$ Ultimately, aboriginal subsistence whaling (ASW) is largely regulated on a national level by the parties in question, acting in conjunction with hunting standards and quotas prescribed by the IWC, with the 'parent' government required to apply for a share of the aboriginal allocation on particular stocks, on the basis of a 'need statement' quantifying the volume of whale meat required by the communities in question. ${ }^{129}$ Despite widespread opposition to commercial whaling within the IWC, aboriginal hunting has been generally accepted as a distinct category of activity that is of fundamental importance to particular communities; broad endorsement is therefore accorded in principle for hunts that do not endanger the populations in question and to which precautionary monitoring and management measures are applicable. ${ }^{130}$

Nevertheless, subsistencequotas - and theirinterpretation-havegenerated occasional discord within the IwC. The aboriginal exemption first received sustained scrutiny in the mid-1970s due to concerns over the potential impact of bowhead whaling by Arctic indigenous communities. ${ }^{131}$ This resulted in a contentious decision by the IWC in 1977 to temporarily ban aboriginal hunts for grey and bowhead whales, ${ }^{132}$ which would eventually trigger the repudiation by Canada of the Convention in $1981 .{ }^{133}$ The bowhead whaling controversy demonstrated that the IWC possessed 'a strong scientific committee but essentially no expertise within its ranks for addressing the socio-economic, cultural and nutritional dimensions of aboriginal whaling.'134 Consequently,

128 Alexander Gillespie, Whaling Diplomacy: Defining Issues in International Environmental Law (Cheltenham, Edward Elgar, 2005) 195.

129 The uncomfortably paternalistic title of this administrative requirement appears likely to be reformulated in the near future: Report of the Aboriginal Subsistence Whaling (ASW) Sub-Committee 2016; Document IWc/66/Repo3, 20.

130 Randall R. Reeves, "The Origins and Character of "Aboriginal Subsistence" Whaling: A Global Review' (2002) 32 Mammal Review 71, 73.

131 John Walsh, "Moratorium for the Bowhead: Eskimo Whaling on Ice?" (1977) 197 Science 847 .

132 For a full account of this issue see IWC (n. 82) 2.

133 See further Ted L. McDorman, "Canada and Whaling: An Analysis of Article 65 of the Law of the Sea Convention" (1998) 29 Ocean Development and International Law 179. Canada therefore regulates Inuit whaling outside the auspices of the IWC; of the other Arctic coastal states that practice Aboriginal Subsistence Whaling, Demark (in respect of Greenland), the us and Russia remain parties to the Convention and follow these specific processes.

134 Reeves (n. 130) 72. 
an Aboriginal Subsistence Whaling Sub-Committee (ASwsc) was established in 1983 to review quota applications and provide advice on technical management measures. Under the auspices of this body, the IWC has subsequently focused on reducing the numbers of whales struck but not landed, ${ }^{135}$ ensuring the sustainability of specific aboriginal hunts ${ }^{136}$ and improving humane killing methods. ${ }^{137}$ Since 2012, the Aswsc has been supported by an Ad Hoc Aboriginal Subsistence Whaling Working Group to address a number of conceptual difficulties with the Asw regime, ${ }^{138}$ including challenges to the alleged commercialisation of such hunts, as discussed further below.

In the specific context of Arctic Asw, complications have arisen over purported quotas for the Greenlandic Inuit. As noted above, the harvesting of particular species by indigenous hunters has been sporadically controversial within the IWC; aside from the bowhead whaling restrictions of 1977, concerns were raised over the hunting of humpback whales by Greenlanders in 1985 , which also resulted in significant quota reductions for this constituency. ${ }^{139}$ As a result of the considerable short-term difficulties raised by this development, Greenland has formed part of the Danish delegation to the IWC since $1985,{ }^{140}$ although Denmark remains the competent negotiating authority concerning Greenlandic ASW. In 1991 the IWC's Scientific Committee endorsed a need statement submitted by Denmark that 670 tons of whale meat was required annually to meet indigenous subsistence demand, a volume that was reapproved by this body in 2007. ${ }^{141}$ While there is minimal dissent to the grant of an Asw to Greenland, ${ }^{142}$ elements of Greenlandic activities under this broad

135 Resolution 1981-4: Resolution to the Government of the United States on the Behring Sea Bowhead Whale.

136 Resolution 1998-9: Resolution on Directed Takes of White Whales; Resolution 1994-4 Resolution on a Review of Aboriginal Subsistence Whaling.

137 In this respect, particular concerns have been raised over the Faroese drive huntsee Resolution 1993-2: Resolution on Pilot Whales and Resolution 1995-1: Resolution on Killing Methods in the Pilot Whale Drive Hunt. More generally the IWC has sought to improve the humane killing element of all aboriginal hunts-see Resolution 1985-3: Resolution on Humane Killing in Aboriginal Subsistence Whaling; Resolution 1997-1: Resolution on Improving the Humaneness of Aboriginal Subsistence Whaling; and Resolution 2001-2: Resolution on Whale Killing Methods.

138 IWC, Annual Report of the International Whaling Commission 2011 (Cambridge, IWC, 2011) 18.

139 Caulfield (n. 84) 127.

140 Ibid., 129.

141 IWC, Annual Report of the International Whaling Commission 2008 (Cambridge, IWC, 2008) 19 .

142 The only meaningful conceptual opposition to Asw has been raised by India, which has called for indigenous communities globally to find alternative food sources: IWC 
umbrella have grown steadily more contentious within the IWC, with concerns raised by the particular species intended to be harvested to meet these nutritional requirements, as well as the alleged commercialization of subsistence catches.

Greenlandic whaling quotas provide an illuminating example of the collective bargaining practices of the $\mathrm{EU}$, as well as the position of individual Member States in seeking to further the objectives of indigenous communities within their dependent territories. Membership of the IWC was first mooted by the EEC in $1979,{ }^{143}$ with a proactive common position against whaling considered as a potential political goal in $1980 .{ }^{144}$ The ICRW currently precludes accession by non-states, ${ }^{145}$ hence formal membership of the IWC would require an amendment of the Convention as advocated by the European Commission in 1992. ${ }^{146}$ Accordingly, none of these proposed approaches were ultimately applied and the EU currently maintains observer status at the IWC. However, in 2007 the Commission adopted a further proposal to advance a common EU position to be followed by the Member States party to the ICRW at future IWC Meetings. ${ }^{147}$ To this end, the Commission argued that the current 'EC policy on whales will not be effective in Community waters if it is not backed by coherent worldwide action, ${ }^{148}$ calling for an aligned position on inter alia the continuation of the moratorium on commercial hunting and support for aboriginal subsistence hunting, and for all Member States to become parties

(n. 138) 15. India acceded to the ICRW in 1985 with the specific aim of ending all categories of whaling, including Asw: Anthony D'Amato and Sudhir K. Chopra, 'Whales: Their Emerging Right to Life' (1991) 85 American Journal of International Law 21, 47. Ironically, the main constituency objecting to the categorisation of Greenlandic whaling as 'aboriginal' is the Greenlanders themselves, who seek the eventual allocation of a commercial quota: Nordic Council (n. 20) 48. At the IWC's 2016 Meeting a contentious draft Resolution on Food Security tabled by a cohort of African parties was defeated, although it appears likely to be raised again in 2018. While ostensibly a measure that might be viewed as bolstering aboriginal claims, the draft Resolution ultimately sought the official recognition of whales as a general food source of global significance-a proposition that was deemed objectionable by a considerable number of parties, including the EU bloc.

143 сом (79) 364.

144 European Parliament (n. 96).

145 Article III refers to the Membership of 'Contracting Governments' within the IWC (emphasis added).

146 сом $(92) 316$.

147 сом (2007) 871. The common position was ultimately adopted in EU Council Decision 9818/08.

148 Ibid., 6. 
to the ICRW. ${ }^{149}$ An official EU common position on whaling was therefore advanced for the first time at the IWC's Sixtieth Meeting in 2008, a development that drew the ire of a number of contracting parties since a 'blocking majority' was now held and coordinated by a non-member that could not be realistically lobbied by other parties at this forum. ${ }^{150}$ Despite these concerns, a common position has been elaborated for subsequent Meetings to 2011, 151 and for the medium-term. ${ }^{152}$ Meanwhile, Denmark has opted out of the common positon by invoking Declaration 25 annexed to the Maastricht Treaty, ${ }^{153}$ which allows a Member States to depart from such policies in respect of overseas countries and territories. Denmark continues to represent Greenland at IWC Meetings in a manner that has led to both conflict and consensus with the EU over Asw quotas.

The conflict between Greenlandic whaling aspirations and the EU centres upon EU endorsement of ASW on the condition that 'conservation is not compromised, whaling operations are properly regulated and catches remain with the scope of documented and recognised sustainable needs'. ${ }^{154}$ While the metric tonnage of whale meat sought by Greenland has received broad acceptance within the IWC's institutions, there has been profound disagreement over the means by which this is to be secured. In essence, Greenland has sought an ASW quota that incorporates an elevated number of humpback whales, a species that would yield a higher quantity of meat and thus reduce the number of individual animals required, but drawn from stocks for which there remains a degree of conservation concern. Despite having the support of the Scientific Committee, proposals to this effect tabled in 2008 were defeated due to the EU's collective bloc vote, which drew an aggrieved response from Denmark's indigenous representatives. ${ }^{155}$ Similar proposals failed to gain sufficient support in 2009, although in 2010 negotiations between Denmark and the EU bloc

149 Ibid., 9. The current cohort of Eu Member States Party to the ICRW numbers twenty-five, with Latvia and Malta yet to accede, while Greece formally withdrew from the Convention in 2013. This also includes the UK, in advance of its prospective withdrawal from the EU in 2019 .

150 IWC 2008 (n. 141) 21. Similar concerns have been directed at the EU in its collective activities in other fora: Richard Caddell, 'Biodiversity Loss and the Prospects for International Co-Operation: EU Law and the Conservation of Migratory Species of Wild Animals' (2008) 8 Yearbook of European Environmental Law 218, 247.

$15^{1}$ EU Council Decision 7146/og.

$15^{2}$ EU Council Decision 17641/11.

153 Treaty on European Union [1992] oJ C191. On the development of the Danish position see Fitzmaurice (n. 121) 213-214.

154 (n. 147) 9.

155 IWC 2008 (n. 141) 23. 
over a reduction in catches of fin whales resulted in a compromise settlement that served to 'reconcile Greenland's requirements while also addressing the European Union's concern for not seeing an increase in the number of large whales struck,',156 thus forming an irresistible majority and securing the requisite consensus to permit a quota on this basis.

Nevertheless, having benefitted from the voting power of the EU bloc in 2010, a subsequent quota request by Greenland submitted in 2012 involving a higher number of humpback whales was again defeated by collective action, with the EU 'unable to support the proposal described', despite reaffirming its general commitment to 'protecting the lives of indigenous peoples, including the protection of livelihoods. ${ }^{157}$ The failure to secure sufficient support for an Asw quota at this meeting would have significant consequences, as administrative restructuring meant that the IWC would meet on a two-yearly basis subsequent to this meeting and Greenlandic quotas would not therefore be reconsidered until 2014. In the meantime the harvesting of particular whales by Greenlanders, which occurred in both 2012 and 2013, was instituted unilaterally by Denmark. Since this was technically conducted without the formal amendment of the ICRW Schedule, a group of (non-EU) parties sought to censure Denmark before the IWC's Infractions Committee. This motion was ultimately rejected, ${ }^{158}$ but the frustrations of the Inuit prompted the Danish authorities to warn the IWC that repudiation of the Convention was being seriously contemplated. ${ }^{159}$

In 2014 a solution to the immediate problem of Greenlandic ASW was brokered at the IWC, with the express support and co-leadership of the Eu bloc. This time, the Danish proposals were accompanied by an updated need statement, calling for 799 tons of meat drawn primarily from the most abundant available stocks as advised by the Scientific Committee, and explicit recognition that these requests constituted a 'package' alongside an EU-sponsored

156 IWC, Annual Report of the International Whaling Commission 2010 (Cambridge, IWC, 2010) 19 .

157 IWC, Annual Report of the International Whaling Commission 2012 (Cambridge, IWC, 2012) $20-22$.

158 Report of the Infractions Sub-Committee; Document IWc/65/Repo4 2. It has, however, been convincingly argued that the Danish actions constituted a technical breach of the Convention, although the consequences may be unclear since there is no clear consensus on the meaning of an 'infraction' for the purposes of the ICRW: Chris Wold and Michael D. Kearney, 'The Legal Effect of Greenland's Unilateral Aboriginal Subsistence Whale Hunt' (2015) 30 American University International Law Review 561, 607.

159 Letter of 1 July 2013 from Denmark to the IWC; reproduced at https://iwc.int/ document_3323. 
Resolution on ASW..$^{160}$ This change in policy was necessitated by continued opposition among a vociferous minority of parties to the perceived commercial nature of at least some elements of the Greenlandic quota, an issue that the resultant Resolution sought to prioritise within the Ad Hoc Asw Working Group. ${ }^{161}$ Despite some initial misgivings that the Resolution was overly focused on Greenlandic activities rather than Asw generally, the spirit of partnership between the EU and Greenland - as well as the assistance of a formidable voting majority - ultimately persuaded a sufficient cohort of parties to endorse this package deal in full. ${ }^{162}$

Conceptually, however, the spectre of commercialization continues to defy a clear consensus on the harvesting of marine mammals by indigenous communities. In a whaling context, the IWC has long recognized that a degree of commerciality is inherent in ASW activities. In 1981, in light of the bowhead whaling controversy, the IWC sought to clarify the Asw regime, observing that commercial considerations played a key role in the continued viability of indigenous hunting, since 'the contemporary whaling system depends on cash income for purchasing equipment'. ${ }^{163}$ Nevertheless, objections to a perceived creeping commercialization of Greenlandic operations have been raised within the IWC since $1985 .{ }^{164}$ In 2004 the IWC adopted a more extensive definition of aboriginal subsistence use, accepting that:

The barter, trade or sharing of whale products in their harvested form with relatives of the participants in the harvest, with others in the local community or with persons in locations other than local community with whom local residents share familial, social cultural or economic ties. A generalized currency is involved in this barter and trade, but the predominant portion of the products from such whales are originally directly consumed or utilised in their harvested form within the local community. ${ }^{165}$

Greenland has contended that the distinction between ASW and commercial whaling is 'artificial', since there is no concerted effort to secure a profit from these endeavours and that any resultant income merely serves to underwrite

\footnotetext{
16o IWC, Report of the 65th Meeting of the International Whaling Commission (Cambridge, IWC, 2014) 10.

161 Resolution 2014-1: Resolution on Aboriginal Subsistence Whaling.

162 IWC 2014 (n. 160) 11.

163 IWC 1982 (n. 82) 38 .

164 Caulfield (n. 88) 264.

165 IWC, Annual Report of the International Whaling Commission 2004 (Cambridge, IWC, 2004) $15^{-17}$ (emphasis added).
} 
the costs of future whaling operations and the increasingly stringent animal welfare requirements for subsistence hunting. ${ }^{166}$ Concerns have nonetheless been expressed that whale meat has been sold in increasing quantities to tourists in Greenland, with some parties suggesting that the Asw quotas are being manipulated to generate enhanced revenue streams within a limited economic environment. ${ }^{167}$

The precise threshold by which commercialization is triggered within indigenous activities remains a controversial and ambiguous issue, not least since many Inuit societies have a complex relationship with hard currency. ${ }^{168}$ Notwithstanding long-standing support for Inuit hunting activities, the number of whales taken for Asw purposes has approached commercial levels in recent years, ${ }^{169}$ a trend that has also raised alarm in the context of seals. Indeed, in EC-Seal Products, the WTo's Appellate Body expressly rejected the assertion by the EU that questions of commercialization became 'irrelevant' once a hunt had been approved under the IC exception, ruling that the subsistence or partial use criteria of the seal provisions 'would appear to call for, if not continuous, at least regular reassessments, at a sufficiently disaggregated level, of whether the requirements of the IC exception are fulfilled.'170 Similar concerns are apparent in the context of whaling, where the 'predominant portion' test remains largely unexplored. Greenland has suggested that the predominant portion of an Asw catch should be construed as comprising at least half of the volume of meat taken. ${ }^{171}$ This would appear at first blush to be a relatively low threshold, albeit one that is heavily complicated by questions over the degree of financial supplementation necessary in any given whaling season to meet the Asw hunting conditions imposed by the IWC. At present, given its stated intention to be 'guided by the precautionary principle and by the advice of the Scientific Committee and also taking into account the work of the IWC's ASW Working Group'172 the EU continues to endorse a degree of local commercialization in Greenlandic subsistence whaling, which 'provides a balanced solution to a complex issue in a manner which is fully consistent

\footnotetext{
166 IWC, Annual Report of the International Whaling Commission 2009 (Cambridge, IWC, 2009) 23 .

167 IWC 2012 (n. 157) 22-24.

168 Caulfield (n. 84) 143-144.

169 Indeed, in 2014 Asw accounted for over 9700 individual whales, compared to some 16,039 for scientific purposes and 23,484 taken under reservations to the commercial moratorium: IWC statistics, reproduced in Wold and Kearney (n. 158) 564.

$170 \quad$ EC-Seal Products (n. 45) para. 5.326.

171 IWC 2008 (n. 141) 20.

172 IWC 2012 (n. 157) 20.
} 
with the established EU position on whaling.173 Nevertheless, given the previous practice of the EU in the pursuit of its common position, this approach may be subject to modification in the light of further IwC clarification of its rules on commercial uses of Asw quotas.

\subsubsection{Compliance Monitoring: The EU and CITES}

In addition to the governance of ASW under the ICRW, oversight of the trade in cetacean products derived from indigenous hunting activities-and their propensity to engage the regulatory attentions of the EU negotiating blochas also been addressed through cites. Unlike more holistic regimes, Cites maintains a highly specific focus upon the conservation problems posed by the international trade in endangered species. CITES operates by listing protected species in one of three Appendices according to their individual conservation status. Under Article II(1), Appendix I includes all species threatened with extinction which are or may be threatened by trade. Trade in these species is subject to 'particularly strict regulation in order not to endanger further their survival and must only be authorised in exceptional circumstances'. At present twenty-one species of cetaceans are listed on Appendix I, predominantly the larger species of whales. Appendix II addresses all species which 'although not necessarily threatened with extinction may become so unless trade in specimens of such species is subject to strict regulation in order to avoid utilisation incompatible with their survival. ${ }^{174}$ Additionally, species may be listed in Appendix II if they do not fulfil this criterion, but nevertheless require protection in order to bring trade in such species under effective control; 'all species' of cetaceans not currently listed in Appendix I have been listed in Appendix II. CITES and the IWC have endured a somewhat fractious relationship concerning whales, however, due predominantly to attempted forum shopping by mutual parties seeking to undermine the moratorium on commercial hunting. ${ }^{175}$

The EU maintains a powerful collective presence within cites. While initially open to participation solely by states, the Convention had nonetheless recognised that its provisions could have implications for treaties that

\footnotetext{
173 Answer of 5 January 2015 to Written Question E-008007-14.

174 Article II(2).

175 See Alexander Gillespie, 'Forum Shopping in International Environmental Law: The IWC, CITES and the Management of Cetaceans' (2002) 33 Ocean Development and International Law 17; on the current relationship between CITES and the IWC see Richard Caddell, 'Inter-Treaty Cooperation, Biodiversity Conservation and the Trade in Endangered Species' (2013) 22 Review of European, Comparative and International Environmental Law 264, 267-269.
} 
maintain a common customs union or removed customs controls between particular countries. ${ }^{176}$ In 1983 the so-called 'Gabarone amendment' to CITES permitted the accession of 'regional economic integration organisations.'177 The amendment entered into effect in 2013, permitting the $\mathrm{EU}$ to become a formal party in July 2015. ${ }^{178}$ Prior to this, the EU formulated a collective position to be advanced by its Member States at CITES meetings. The EU still bargains collectively within the cITES institutions and each of the EU's current complement of Member States also remains party to the Convention in an individual capacity. The formal accession of the EU to CITES will not, however, effect the extent of its bloc vote, which will continue to be commensurate with the number of its constituent Member States. ${ }^{179}$

Despite being initially precluded from acceding to CITES, since 1982 the EU has adopted periodic legislation to give effect to the terms of the Convention. ${ }^{180}$ As with CITES itself, the EU provisions apply a list-based regime. However, the CiTES Regulation departs from cites practice by allowing for the listing of some Appendix II species in its Annex A which denotes species subject to the most significant restrictions on trade. This is significant since all species of cetaceans are listed on the Regulation's Annex A. ${ }^{181}$ An exemption is however granted to specimens listed on CITES Appendix II 'including products and derivatives other than meat products for commercial purposes, taken by the people of Greenland under licence granted by the competent authority concerned', which are instead listed in Annex B of the Regulation. ${ }^{182}$ This listing

$176 \operatorname{Art} \operatorname{xiv}(3)$.

$177 \operatorname{Art} \operatorname{XXI}(2)$ (as amended).

178 Council Decision (EU) 2015/451 of 6 March concerning the accession of the European Union to the Convention on International Trade in Endangered Species of Wild Fauna and Flora (CITES) [2015] OJ L 75/1. The EU accordingly participated for the first time as an official party to CITES at its Seventeenth Conference of the Parties (COP) to Cites, convened in September and October 2016.

179 Theoretically the EU could be entitled to claim an additional vote as a CITES party in its own right, but has declared that this will not be exercised. The EU will accordingly cast the bloc vote for matters within its competence, whereas individual Member States will vote, based on the pre-established common position: Implications of the EU's Accession to CITES; Document CoP 17 Inf. 20.

180 The inaugural Cites Regulation was adopted by the EEC in 1982 (n. 103); the current iteration of these provisions is Council Regulation 338/97/EC of 3 March 1997 on the protection of species of wild fauna and flora by regulating trade therein [1997] OJ L 61/1.

181 For a full discussion of the machinations of the EU CITES Regulation in relation to whaling activities see Davies (n. 110) 46-51.

182 Annex 12, x703. 
allows for the importation of small amounts of whale products from Greenland, subject to particular administrative and veterinary requirements. ${ }^{183}$

This exemption has proved to be sporadically contentious, primarily in the specific context of the trade in narwhal products. Since 1979 narwhals have been listed on Appendix II of CiTEs and are hunted and consumed solely by the Inuit of Greenland and Canada, ${ }^{184}$ notwithstanding a lucrative market for trinkets carved from the tusks and teeth of these animals. In 1995, concerns over the conservation status of narwhals led to a Review of Significant Trade (RST) in narwhal products under the auspices of CITES, a process that allows for additional scrutiny of the national protection accorded to Appendix II species that are subject to elevated levels of trade. ${ }^{185}$ In 2004, the recommendations arising from the RST were considered to have been complied with by both Greenland and Canada. ${ }^{186}$ Nevertheless, the trade in narwhal items has attracted the sustained concern of the $\mathrm{EU}$, which has exercised a degree of influence over subsequent regulatory events. In December 2004 the EU's Scientific Review Group (SRG), the advisory authority charged with reviewing compliance with ciTes for the purposes of allowing imports of animal products into the internal market, delivered a mixed verdict on narwhals, forming a negative view of Greenlandic products and a positive view of Canadian imports. ${ }^{187}$ At the next meeting of the CIT Es Animals Committee in 2005, however, the EU bloc sought a new RST, ${ }^{188}$ a position that was heavily criticised by Denmark (on behalf of Greenland) 'for having been produced without consultation with the range States and for presenting misleading information'.189 In 2006, a further RST was averted through the adoption of new legislation in Greenland, albeit with significant loopholes-not least an exemption for the

183 Commission Regulation (EC) No 206/2009 of 5 March 2009 on the introduction into the Community of personal consignments of products of animal origin and amending Regulation (EC) No 136/2004 [2009] oJ L 77/1.

184 Narwhals are primarily regulated on a bilateral basis through the Canada-Greenland Joint Commission on Beluga and Narwhal established in 1991, although a series of other multilateral arrangements are applicable to this species: see further Malgosia Fitzmaurice, 'So Much Law So Little Protection! A Case Study of the Protection of the Narwhal' (2009) 1 Yearbook of Polar Law 21.

185 Resolution Conf. 12.8: Review of Significant Trade in Specimens of Appendix-II Species.

186 Fitzmaurice (n. 121) 291.

187 Tanya Shadbolt, Ernest W.T. Cooper and Peter J. Ewins, Breaking the Ice: International Trade in Narwhals, in the Context of a Changing Arctic (Toronto, WWF, 2015) 39.

188 The Need for a New Review of Significant Trade in the Narwhal; Document AC21 Inf.1 (Rev 1).

189 Summary Record of the Twenty-first Meeting of the Animals Committee of CITES (Geneva, CITES, 2005) 11. 
export of tusks as household items for citizens relocating overseas, permitting substantial transfers of narwhal products to Denmark among the Greenlandic diaspora. ${ }^{190}$ Moreover, in 2009 the SRG amended its opinion of Canadian products, thereby allocating the final decision (and an effective veto) over imports from these producers to the national authorities of the individual Member States. ${ }^{191}$ Notwithstanding a minuscule market for narwhal products beyond Greenlandic émigré communities, this position evokes an uncomfortable comparison with the more objectionable aspects of the EU's seal provisions: the import exemptions in the EU CITES Regulation apply only to Greenland, whose products are treated under Annex B of the legislation, yet those derived from the Canadian Inuit continue to fall under the more stringent requirements of Annex A.

\subsubsection{Splendid Isolation: The EU and NAMmCo}

A further forum for the regulation of marine mammals in the High North arises in the somewhat more contentious regional context of NAMMCO. The formation of NAMMCO is commonly perceived as a cautionary tale regarding the uncompromising nature of whaling negotiations in the early $1990{ }^{192}$ Nonetheless, while disillusionment with IWC practices provided a significant political spur to the establishment of this organisation, NAMMCO also provides management advice on the sustainable use of pinnipeds and on fisheries interactions within the region. NAMMCO has been operational since 1992, although an official basis for the coordination of common policies within the region was established through a series of intergovernmental conferences convened between 1988 and 1992. These initiatives led to the adoption in 1990 of a Memorandum of Understanding, which created the scope to develop a formal management body to advance this process further. ${ }^{193}$ In September 1992, the Agreement on Cooperation in Research, Conservation and Management

\footnotetext{
190 See further Fitzmaurice (n. 121) 294.

191 Shadbolt, Cooper and Ewins (n. 187) 39.

192 See David D. Caron, 'The International Whaling Commission and the North Atlantic Marine Mammal Commission: The Institutional Risks of Coercion in Consensual Structures' (1995) 89 American Journal of International Law 154.

193 On the development and early operation of NAM MCO see Alf Håkan Hoel, 'Regionalization of International Whale Management: The Case of the North Atlantic Marine Mammals Commission' (1993) 46 Arctic 116, at 118-21 and Brettny Hardy, 'A Regional Approach to Whaling: How the North Atlantic Marine Mammal Commission is Shifting the Tides for Whale Management' (2006) 17 Duke Journal of Comparative and International Law 169, 179-187.
} 
of Marine Mammals in the North Atlantic ${ }^{194}$ was signed between Iceland, Norway, Greenland and the Faroe Islands, thereby formally bringing NAM MCO into effect. NAMMCO has nevertheless been treated with a degree of suspicion by a number of anti-whaling states, concerned at the possible proliferation of regulatory alternatives to the IWC.

In marked contrast to its practices within the IWC and CITES, the EU has exhibited minimal interest in working with NAMMCO. Indeed, while the EU holds official observer status within this body, ${ }^{195}$ it has yet to attend a single meeting of the NAM MCO Council. This is perhaps unsurprising given the stated collective intent to derive management advice on whaling issues-including ASW matters, on which NAMMCO would appear well-placed to consult-from the IWC, ${ }^{196}$ while the EU has tended to hold regional marine mammal organizations in relatively limited regard, exercising similarly minimal engagement even with fora that are considerably more preservationist in outlook. ${ }^{197}$ The most profound divisions between these bodies nevertheless relate to seal hunting, with NAMMCO representing an obvious forum for the airing of grievances against the seal products legislation and for which the NAMMCO Council has directed sharply-worded criticism of the Eu's refusal to engage with the wealth of available expertise on sustainable hunting issues in the High North. ${ }^{198}$ Indeed, despite submitting a series of expert reports on the hunting and killing of seals to the $\mathrm{EU}, 199$ there is little evidence to suggest that the specific work of NAMMCO in this regard exercised even cursory influence over the trajectory of the EU seal regime, a position reflective of the EU's somewhat haphazard approach to consultations with Inuit interests in the context of the sustainable use of marine mammals.

194 Reproduced at www.nammco.no.

195 In 2016 the NAммсо Council adopted a set of Rules and Procedures for Observers, under which such status will be suspended for an observer that 'engages in activities which are at odds with the NAMMCO Agreement'. While this appears primarily intended to discourage uncooperative personal behaviour at meetings, it may be mischievously speculated whether the Eu's position on seal hunting technically meets this requirement from the perspective of a number of NAMMCO participants.

196 (N. 147) 9.

197 Caddell (n. 150) 247-250; see also Robin Churchill and Daniel Owen, The EC Common Fisheries Policy (Oxford, Oxford University Press, 2010) 383-385.

198 EU Import Ban on Seal Products Contrary to International Principles for Conservation and Sustainable Management, NAM m co Statement of 2 September 2010.

199 NAммсо, Report of the Seventeenth Meeting of the NAMMCO Council (Tromsø, NAM MCO, 2008) 20. 


\section{$4 \quad$ Concluding Remarks}

The position of marine mammals remains one of the more complicated elements of the international regulation of marine living resources. In an era of profound change in the High North, the harvesting and consumption of whales and seals continues to form an integral part of the culture, society and diet of many Arctic indigenous communities. Despite popular support for the preservation of these ancient ways of life, it is equally clear that the killing of charismatic marine mammals provokes significant concerns within Western societies, often resulting in legislative and policy responses that have a propensity to cause inadvertent harm to indigenous interests. Few current issues have illustrated this complicated regulatory dichotomy more explicitly than the purported regulation of marine mammals by the $\mathrm{EU}$, which has exposed significant challenges both in governing the presence of particular products within the internal market, as well as advancing wider policy objectives at an international level.

In this regard, the various provisions on seal hunting have greatly undermined the EU's aspirations and credentials for a significant partnership role within the Arctic. While the $\mathrm{E} U$ has acted peremptorily in a number of instances to impose market restrictions upon particular animal products deemed morally objectionable, notably to protect particular species ${ }^{200}$ or to promote improved trapping standards, few such provisions have provoked the sustained political and legal backlash precipitated by the EU Seal Regime. The initial EEC seal pup pelt ban severely hampered the global market for seal products and damaged Inuit interests in a manner that raised sharp questions as to whether the Community genuinely understood the unique socio-economic conditions of the Arctic. ${ }^{201}$ These concerns have been compounded by the seal products ban, which has proved to be insufficiently nuanced to protect Inuit enterprises and has led to a saga of highly damaging litigation that has reflected poorly upon the EU as a regulatory authority and harmed its wider interests among Arctic governance structures. In this context, the various iterations of the seal legislation can be considered to have clearly failed to meet the EU's stated objectives for the Arctic: traditional livelihoods have suffered greatly as a result of the ban, for which the social and cultural ramifications remain poorly

200 See, for instance, the comparatively more obscure Regulation (EC) No 1523/2007 of the European Parliament and of the Council of 11 December 2007 banning the placing on the market and the import to, or export from, the Community of cat and dog fur, and products containing such fur [2007] oJ L 343/1.

201 Wenzel (n. 16) 129. 
understood, while these provisions have contributed little to promote sustainable development, to engage the native population or to enhance multilateral governance in the region.

At an international level, the Eu's policies towards the whaling interests of indigenous peoples exhibits tentative promise that it may have a valuable partnership role to play within the Arctic. Indeed the EU has proved to be a key constituency in the promotion of subsistence whaling rights, helping to secure aboriginal quotas within the IWC - but essentially on its own terms, using its powerful bloc vote to veto purported allocations from particular stocks. In this manner, while indigenous interests (especially those of Greenland) have benefitted from accepting the EU's interpretation of aboriginal whaling entitlements, a number of adverse consequences have also been apparent for the IWC itself: Inuit hunters have been forced to adopt unilateral quotas when outvoted, there has been a marked deterioration in the transparency of quota allocations due to the prior elaboration of package deals and the issue of Asw has become increasingly polarized in recent years. Of greater concern from the perspective of Arctic constituents is the steadfast refusal of the $\mathrm{EU}$ to engage meaningfully with the notion of sustainable hunting, which remains key to the management ideals of the High North, while there is little evidence to suggest that the significant expertise concerning the sustainable use of marine mammals aggregated within NAMM CO will exert any material influence over the future trajectory of the EU's marine mammal policies. Consequently, there is likely to be limited consideration of sustainable use as a distinct management concept in subsequent approaches by the EU towards marine mammals, which leaves the Community vulnerable to similar regulatory missteps as experienced in the seal context, and to wider criticisms that it still does not fully appreciate the unique governance conditions of the Arctic. Moreover, as with an increasing number of regulatory issues affecting the High North, questions have been raised as to whether the EU has genuinely adopted an Arcticcentric approach, or whether such matters have been advanced on an ad hoc basis with little coordination with wider policy objectives for this region. ${ }^{202}$ Its treatment of marine mammals to date suggests that the EU has largely maintained a single-issue focus and that broader policies towards such species have yet to be effectively integrated into its strategic objectives for the Arctic.

A series of regulatory challenges will continue to confront the $\mathrm{EU}$ in addressing marine mammals - and their consumers - in the Arctic. Chief among these will be repairing the damage inflicted upon Inuit communities

202 Adam Stępién, 'Internal Contradictions and External Anxieties: One Coherent Arctic Policy for the European Union (2015) 7 Yearbook of Polar Law 249, 280-281. 
by the seal products ban, not least in Canada where the sustained discriminatory nature of these provisions has had a particularly significant impact, while Greenland remains deeply aggrieved by the effects of this legislation upon traditional livelihoods. This has already significantly undermined the EU's aspirations for observer status within the Arctic Council, which appears to be contingent upon progress towards a more sympathetic treatment of seal products. $^{203}$ In connection with this, a deeper conceptual question is raised by the increasingly commercial nature of the hunting of marine mammals, which has been exposed both by the seal litigation and ongoing difficulties in regulating ASW within the IWC. The threshold by which a subsistence hunt will graduate to a commercial activity-and the regulatory consequences thereto-raises challenging questions of the current system, but will increasingly require further consideration. Ultimately, however, an effective treatment of these delicate issues is likely to require a more nuanced appreciation of Arctic conditions, as well as greater restraints on EU unilateralism, than has previously been applied in the specific context of marine mammals.

203 Indeed the Nuuk Observer Rules of 2011 expressly addressed the issue of seals: see further Piotr Graczyk and Timo Koivurova, 'A New Era in the Arctic Council's External Relations? Broader Consequences of the Nuuk Observer Rules for Arctic Governance?' (2014) 50 Polar Record 225. 